

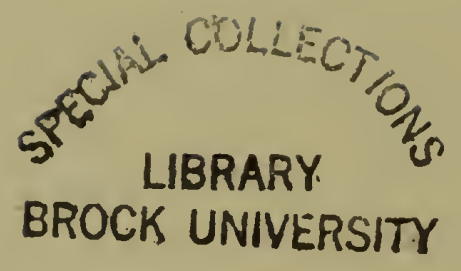

261367 


\section{Fruit Farming in Ontario, Canada}

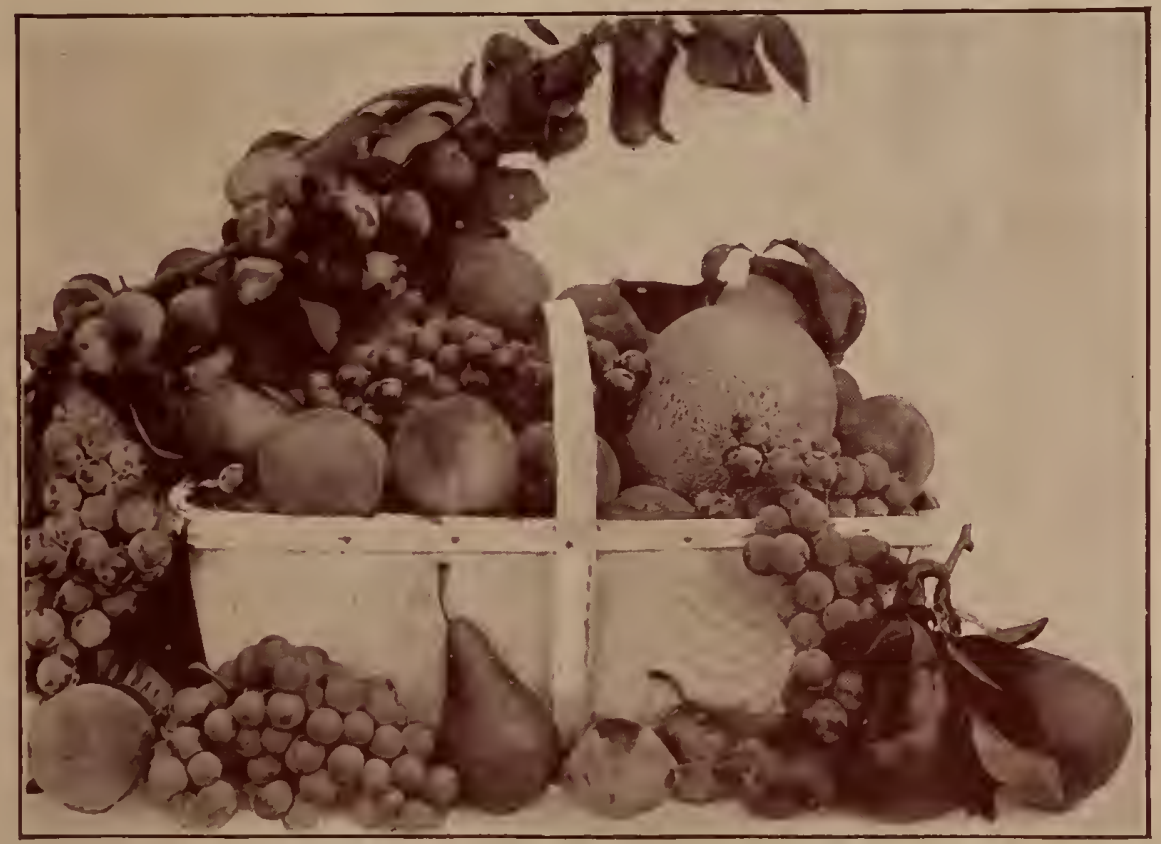

Prepared by direction of the HON. JAMES S. DUFF Minister of Agriculture for the Province of Ontario, 1911

Printed by order of the Legislative Assembly of Ontario. 


\section{The Fruit Belt of Ontario.}

"The gardens and the orchards of Canada were justly reputed to be the best in the world. There were some disadvantages of climatic conditions as compared with the United States, but there were also climatic advantages. The Canadian climate produced apples, peaches and melons inferior to none in the world, and which had first place on the tables of wealth and luxury in New York, London and nther world centres." This will seem incredible to the British people. who have been so much accustomed to think of Canada as "Our Lady of the Snows." But the statement comes from one whose position is so high and responsible that he cannot venture to be anything but deliberate, namely, the Premier of Canada.

The Dominion is a land of many climates, as might be expected where the area is three and a half million square miles, or about equal to that of Europe.

The Province of Ontario alone is 78,000 square miles larger than the British Isles, and here, of course, though to a less degree than in the rest of Canada, there are more climates than one. Its most southern part, on the shore of Lake Erie, is in the same latitude as Northern California, Southern France, and Rome in Italy. It need not therefore bs incredible that Southern Ontario should grow peaches, grapes and tobacco. England, even in its warmest spots, canuot grow peaches, except in a greenhouse, or against a wall with the best exposure to the sun. But in Ontario South they grow abundantly in the open air, and a market may be seen in the season where hundreds of wagons are laden with this delicious fruit, and the air is filled with its fragrance. In this favored Province there are wide stretches of peach orchards and grape vineyards extending over miles.

The fruit belt of Ontario extends from east to west for a distance of over 400 miles, and from north to south for 50 to 150 miles. Here is the home of the king of fruits, the apple, in many varieties; and here also are pears, quinces, plums, cherries, strawberries and other small fruits in abundance. But the tenderer fruits, such as the peach, are only produced to perfection in Ontario South.

Much as is the production of fruit in Ontario, the demand in the Dominion and abroad is greater than the supply, and that demand is increasing with the settlement of Northern Ontario and the North-West.

Besides the sale of fresh fruit, an amazing quantity is tinned at innumerable Canadian canneries, especially in the orchard sections of the Province, for distribution throughout Canada and for shipment to the British Isles and elsewhere. 


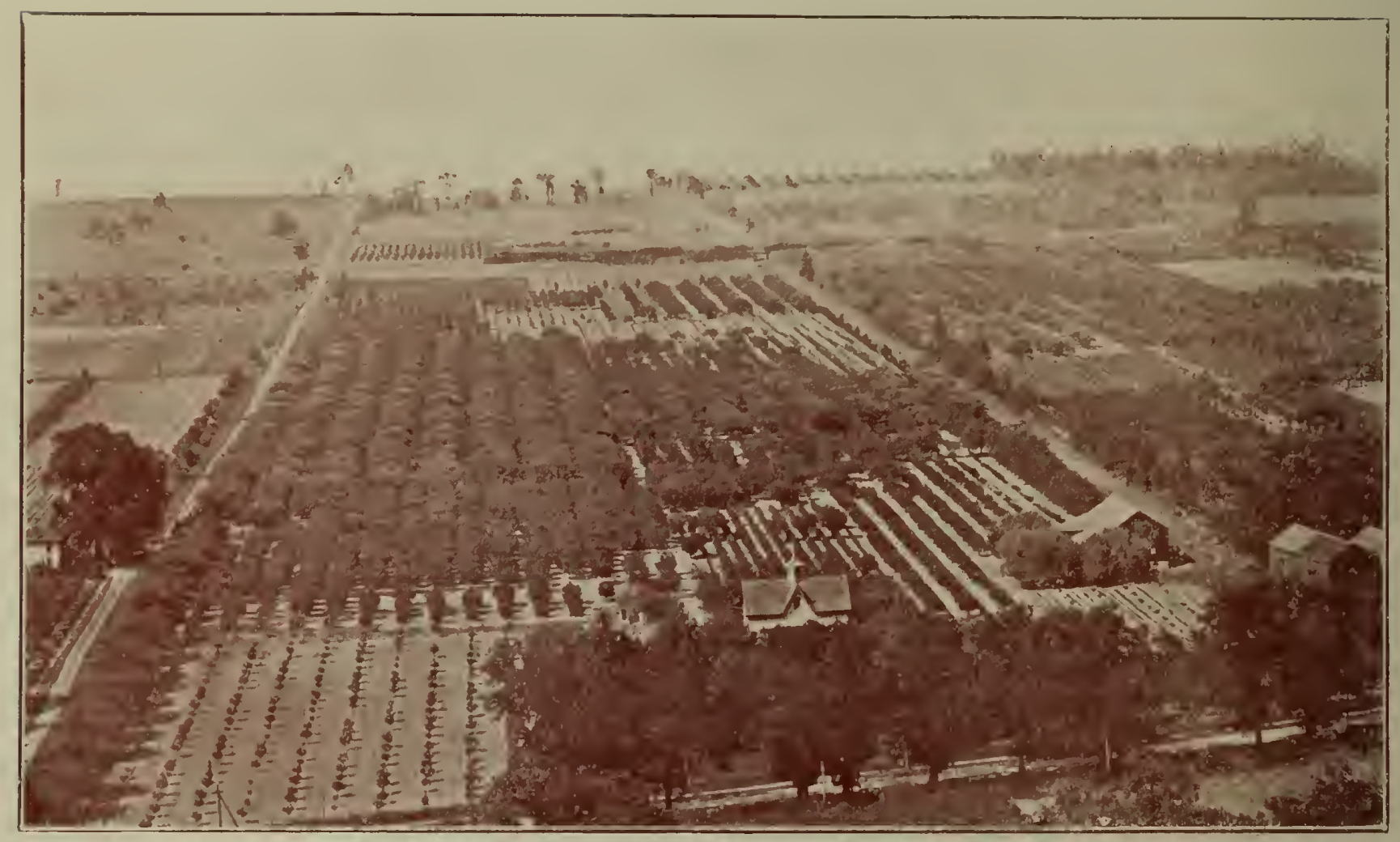

In the Fruit Belt. 
Here then is an opportunity for profitable investment in one of the nearest and most advanced Provinces of the Dominion. If much remains that is primitive in this large l'rowince, it is this very feature that affords the opportunities for lumbering, mining, farıning and fruit-growing. Yet there are large cities, towns and villages with all the attractions and conveniences of modern civilization. And in certain of the fruit districts there are many beautiful homes, from the sweet cottage with its shade trees and pretty garden, to the handsome brick louse with its tennis lawn, beds of flowers and ormamental trees. There is much of social enjoyment, and there are no class distinctions as in the 0ld Land. Not to speak of ordinary educarion, which is of the best, the Provincial Government maintains one of the greatest Agricultural Colleges of Canada, and a number of experimental fruit stations which liclp the fruit grower to find ont quickly what suits his own particular soil, and are of special advantage to the inexperienced immigrant. And therc are also co-operative societies, which enable the producer to get the whole profit of his production.

The man of some capital, and especially the man acquainted with fruit-growing, will meet with success. The work is honest effort, healthful enjoyment and independent life. It is not drudgery. Labor-saving machinery has modified that. But capital or no capital, knowledge or no knowledge, the able-bodied resolute man of the British Isles has a great offer given him from the fruit-belt of Ontario.

\section{WHY ONTARIO LEADS.}

\section{Remarkable Results.}

Ontario produces 60 per cent. of all the pluns grown in Canada.

Ontario produces 70 per cent. of all the apples grown in Canada.

Ontario produces 80 per cent. of all the small fruits grown in Canada.

Ontario produces 80 per cent. of all the pears grown in Canada.

Ontario produces 99 per cent. of all the peaches grown in Canada.

Ontario produces 99 per cent. of all the grapes grown in Canada.

Ontario Produces 75 per cent. of all Fruits Grown in Canada.

There are reasons for the remarkable results achicred. Nature and mankind have joined hands. 'The fruit grower reaps the bencfit of ideal natural conditions and exceptional modern advantagas and facilities. Everything contributes to lis success.

\section{The Reasons in a Nutshell.}

Ontario leads in fruit growing because here the fruit grower finds:

A suitable soil.

An ideal climate. 
Land reasonable prices.

A big and growing market.

Unsurpassed transportation facilities.

Records of large commercial returns.

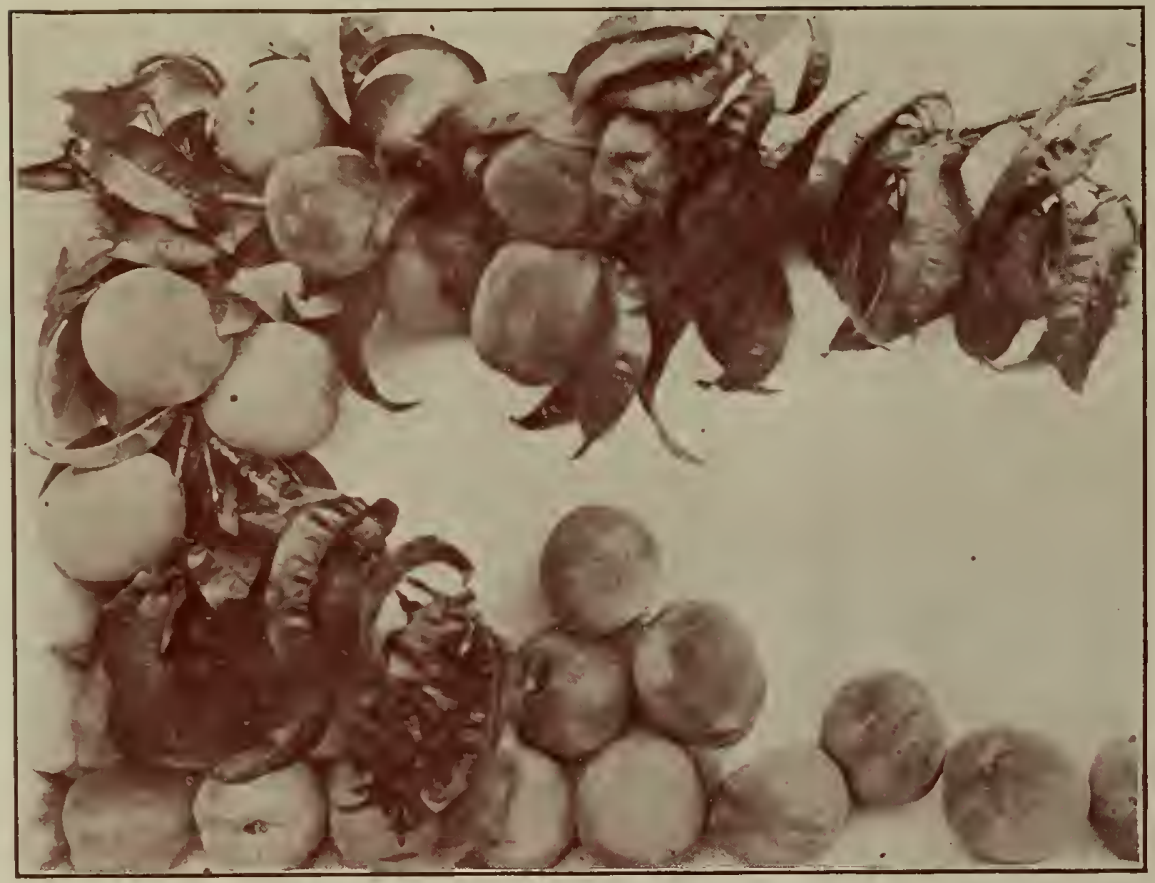

Crawford Peaches-a Popular Variety.
A sufficient rainfall with no need for irrigation.

The opportunity to acquire almost any acreage required.

A reputation for excellent fruit products, which is a world-wide asset.

Government experimental stations to give the fruit-grower counsel free of cost.

The active aid and consideration of the Provincial Department of Agriculture.

Co-operative societies and associations to ençourage and assist the individual fruit-grower.

Ontario offers big opportunitics for industry and enterprise. The capital required is comparatively small. The return on the investment is large. immediate and sure.

\section{Ontario Soil.}

There are many soils, suited to a variety of fruits.

Apples do well on clay loam or gravelly or sandy soil.

PeAches thrive on sandy loam.

GRapes AND PEars prefer a clay soil.

PuUMs grow on a variety of soils, but prefer the heavier types. 
Cherries find their ideal conditions in a light, sharp gravel, well drained.

Strawberries aNd RAspberries thrive on a rich sandy loam.

\section{Ontario's Ideal Rainfall Makes Irri= gation Unnecessary.}

Fruit-growers in Ontario have great arrantages orer their neighbors in Western Canada and the United States, by reason of its remarkably advantageous climate. Other fruitgrowing districts there are, particularly in the west. But these lack many of the natural adrantages with which this Province is blessed. Ontario is situated adjoining the Great Lakes of Canada, and to her an abundant rainfall is always insured. Ontario's fruit-growers are not confronted with any of the problems of irrigation, or other artificial methods

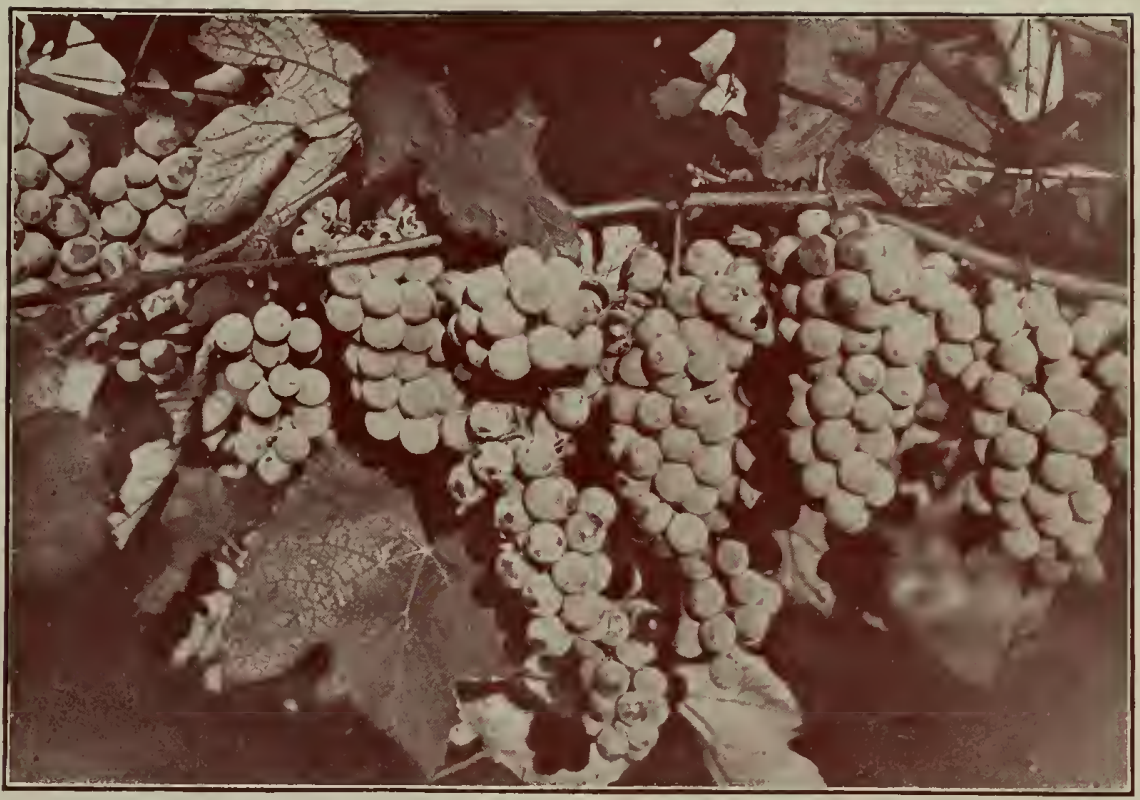

Grapes-A Standard White Variety of Excellent Quality. of securing needed moisture. Her climate is ideal-a happy combination of refreshing and plentiful rainfall and delightful sunshine. Nature has dealt towards her with lavish generosity. There are no natural handienps. The Ontario fruit-grower starts hand-in-hand with Nature. They work together for the remarkable results achieved. There is no preliminary work or expense; no irrigation problems to solve. That is why Ontario leads the new world in fruit growing. 


\section{THE LAND OF PROMISE.}

Ontario is the Iand of Promise to the enterprising settler who proposes to grow fruit. Its opportunities to him are mequalled anywhere else. It is the home of the suecesful and profitable orchard.

Onlarin possesses the best fruit-growing areas in the greant new world. Her soil and climate insure quality in all agricultural products. Upon her wide and fertile acres groneral farming, fruit growing, market gardening, and the kindred business of sucsessul vegetable production have all proved splendid eonmercial enterprises.

\section{The Call.}

To the practical man -the man of ambition - the man at present on rented land-the man desirous of securing a fow arres of his own, mpon which to establish his home and support himself and his family in liealth, happiness and contentment - to him the fruit growing lands of Ontario send forth their vall. Tere the opportunity awaits. Notwithstanding the fact that Ontario already produces three-fourths of all fruits grown in Canada, the fruit industry is, as ret, not much more than in its infancy. The? intending mureliaser slonld not fail to write to, or eonsult, the Gorernment Department of Agriculture for the Province. Here lie will obtain, free of cost, expert advice and assistance.

\section{Conditions are Congenial.}

Ontario's fruit growing lancls are aclmirably situater? ('ongenial concitions obtain. The pioneer work, with ali its attendant hardships, has been done. 'The country has been settled for a hundred years and nore. Law and order prevail. Taxes are light. Railways travere the country, providing ready transportation for the products of the soil. (ities, towns and villages-dotting the map everywhere-afford an eager and amplo market. Good roads, schools, churches, mail servion. newpapers, tolegraph, telephone, and the thousmol and one material advantages which ard to the amenities of life, are factors in the make-up of present-lay rural conditions in Ontario. In such conditions the fruit growing settler founds lis new home.

\section{What has Been Done.}

Fruit growing is not an experiment in Ontario. There are already orer 336,398 acres of orelard, vincrard and small fruit gardens. The acreage is growing, rear by rear. Nearly every farmer now has an orchard. Thic chicf fruits are all of a homely, usefnl, commercial kint -the apple, peich, pear, grape, quince, plum, cherry, strawherry, rapherry, gonseberty, black and red currant. etc. From almost every section of the Provine come reports as to the great possibilities proved to exist for the successful growing of these fruits. The Department of 
Agriculture will, upon application, be pleased to furnish to anyone interested, maps and literature dealing with and describing in detail the raried favored fruit districts of Ontario.

\section{The Waiting Market.}

The excellence of the fruit output and the enterprise of the Department has resulted in. rapidly expanding the warket. Every year has witnessed an increasing demand. Every year has brought new fruits for shipment. The growth of honie population in centres along the railways has called for car-loads, and big warelouses are being built to distribute the fruit and more effectually grapple with the demand -a demand so great that Ontario cannot as yet keep pace with it. The markets of Great Britain alone call for all the apples which can be sent, provided they are of good variety and well packed. For peaches, grapes, plums, pears, early apples, etc., the markets of the great Northwest are making demand in ever increasing volume. Moreover, large quantities find a ready sale in the United States, where according to Tnited States authorities, the production of apples has steadily decreased each year from $69,070,000$ barrels in 1896 to $22,735,000$ in 1909 . Strawherries and other small fruits find peremial ready sale in the rities and towns at the doors of the grower. The central situation of $\mathrm{On}$ tario is most adrantageous to both the Fastein and the
Western markets, and her fruit products are continually finding wider distribution. The development and settlement of the great l'rairie Provinces expanding every year-ofler an almost limitless Canadian market, and hundreds of centres of population along the different lines of railway have their fruit consigned to them in carload lots.

\section{Government $\mathrm{Co}_{0}=$ Operation}

T'he Government of Ontario is daing much to develop the fruit industry and to co-operate with the fruit grower in the expansion of his business. In the apple growing sections part of the output is gathered together, packed and shipped through co-operative associations of fruit growers, of which there are some thirty-seven operating at the present time. 'The great bulk of the crop, however, is handled by dealers, who buy the product of the orchards, either in bulk or by the barrel, have it packed and -hipped in carload lots on consignment to Great Britain. Transportation is becoming increasingly efficient, especially in the southern parts where tender fruits are handled. 'To secure accurate knowledge on the problem of ascertaining the varieties of fruit best adapted to different localities and conditions, systematic experinents were conflucted for a number of years at thirteen different points, under the auspices of the Ontario Department of Agriculture. With the results before him, the grower is not likely to go very far wrong in his choice of varieties. 


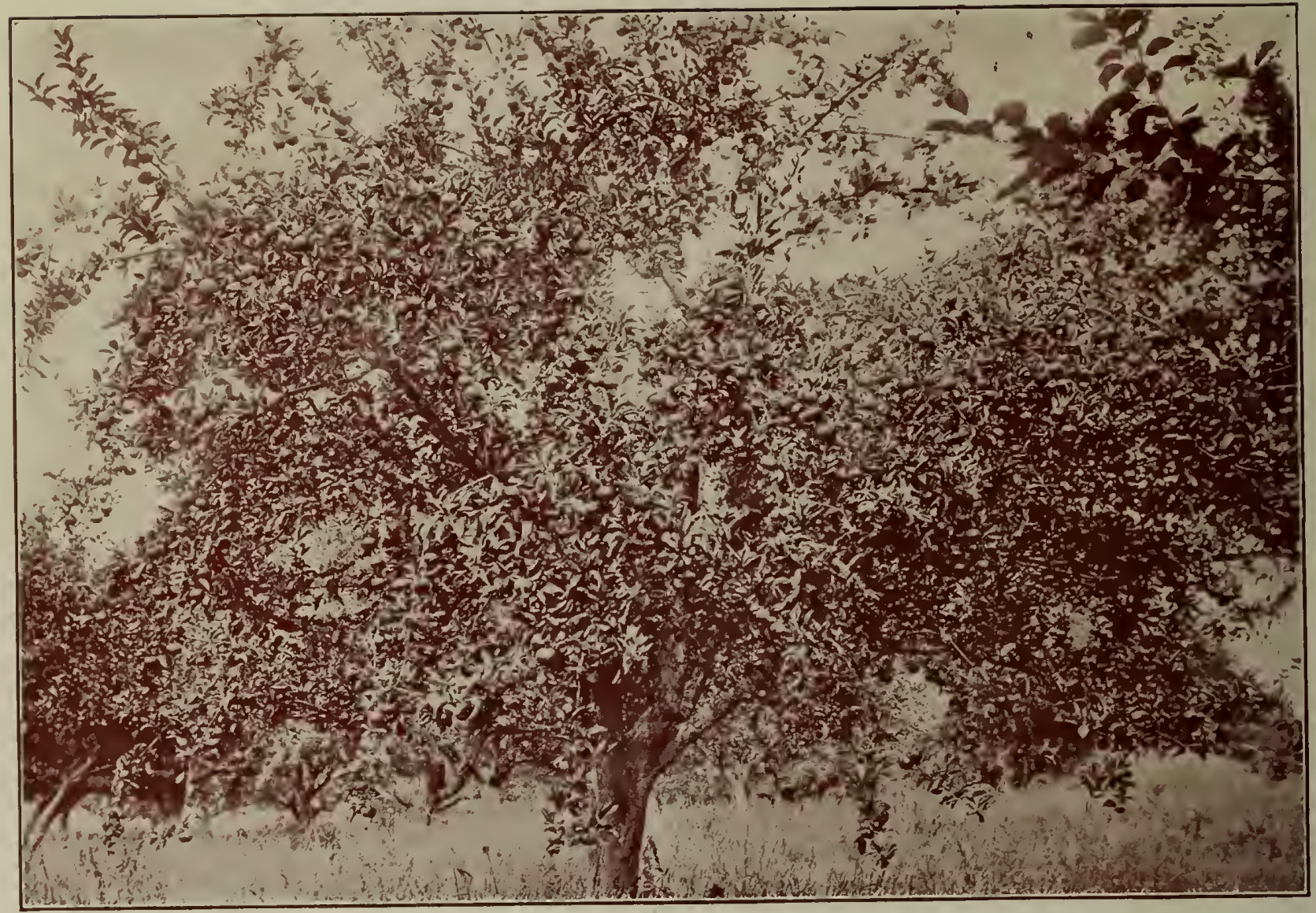

Apple-Growing Without Cultivation. 


\section{Aid Given by Experts.}

Following up the work of the local stations, a central horticultural experiment station has been established by the Government at Jordan Harbor in the Niagara district to experiment, not only with varieties of fruit and vegetables, but with soils, methods of culture, the improvement of old varieties and the originating of new ones. The Ontario Fruit Growers' Association, the Niagara Peninsulq Fruit Growers' Association, and the Ontario Vegetab!e Growers' Association are other leading organizations for the purpose of assisting growers and safeguarding their commercial interests. The report of the Ontario Associations, published annually by the Government, contains information of value to the grower on all matters pertaining to his business.

\section{Some Striking Figures.}

There are $16,700,0 \mathrm{C} 0$ fruit trees now yielding product in Ontario, while the annual arerage value of the Ontario fruit incustry is $* \$ 7,511,611$; the capital value, $\$ 55,426$,071 ; and the acreage $30 \%, 77 \%$.

From 700,000 to $1,000,000$ barrels of Ontario apples are exported annually, chiefly to Great Britain, and from 200,000 to 300,000 barrels to the Western Provinces. The report of the Ontario Bureau of Industries shows that the yield of apples in one year from the orchards of Ontario totalled $35,006,991$ bushels.

$* \$ 1=4$ s, 1 łd.
The total number of acres devoted to the growing of small fruits in 1908 was $11,199$.

\section{Growth has been Natural.}

Ontario's fruit growing industry is cne that has grown up naturally, without any attempt at exploitation, as soil and climate conditions have made the suitability of the country for this purpose self-evident. It will be interesting, however, to note individually, some of the kinds of fruit grown, and the results attained by industrious and enterprising growers.

\section{Estimates on a Fair Basis.}

The practical man looks at results. Upon what has been done a reliable estimate for the future can be formed. What has Ontario fruit growing accomplished in figures?

As in all lines of human endeavor the amount of money to be made in the business depends largely upon the man who is runing it. It is not the policy of the Ontario Department of Agriculture to present the "exceptional" figures. This leads to an expectation of such results as are seldom realized. Frequently a small sum wisely expended may bring wonderful results, but it is not safe to take such instances as a basis for general results.

Ontario presents estimates on average results, on statements supplied by those who have embarked in the business under conditions similar to those that will confront 


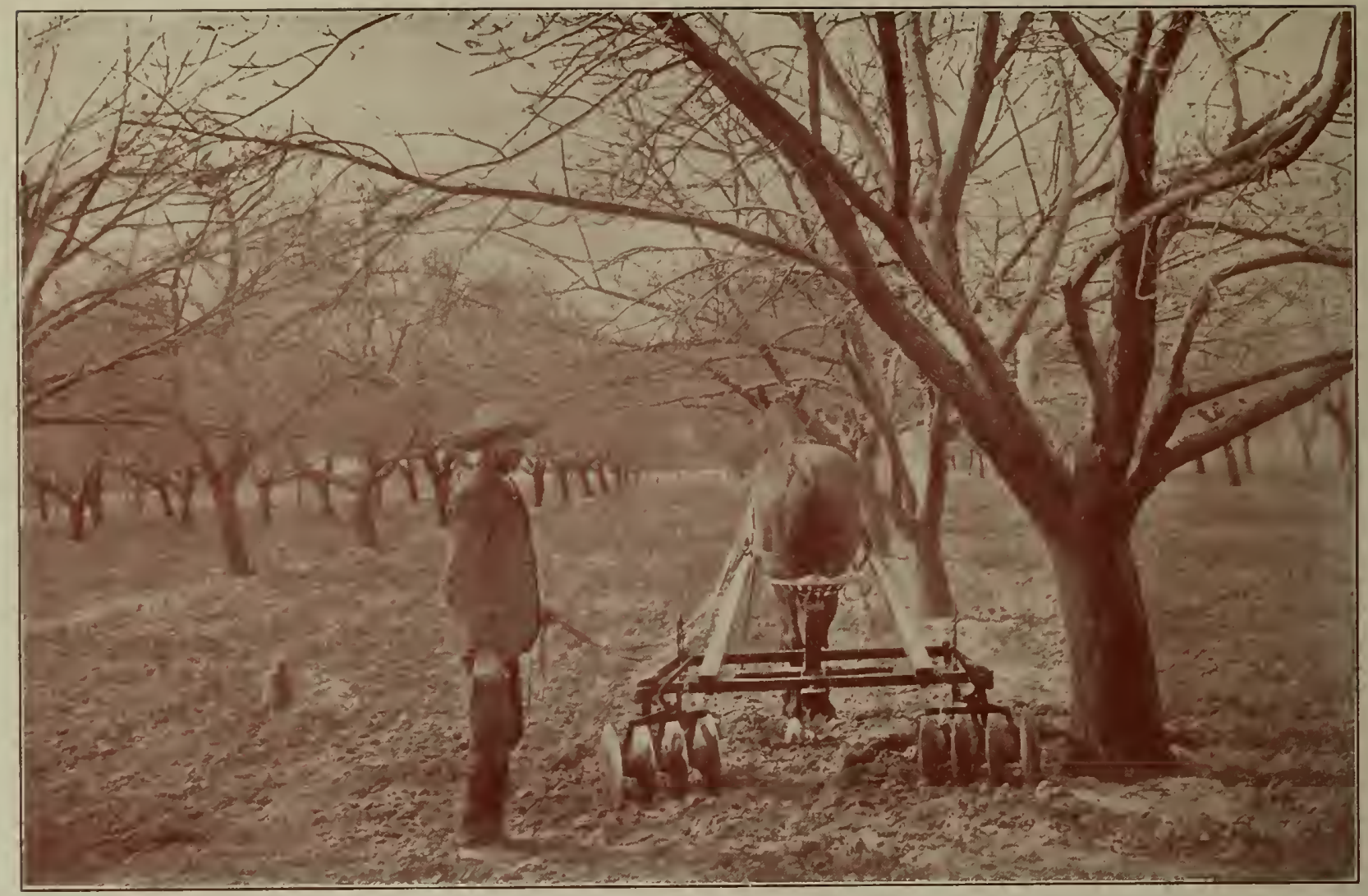

Spring Cultivation. 
the settler. Most of these men have worked on a large scale, and their testimony is that the business of fruitgrowing in Ontario is a very profitable one. In all examples it will be noted that nothing is allowed for interest on money invested.

\section{THE KING OF FRUITS.}

Ontario is the home of the king of fruits. The capacity of the Province for producing apples is simply extraordinary, and the output furnishes its largest fruit interest. It has yet vast unplanted areas suitable for growing this fruit, and, in view of advancing prices and the splendid quality of the product, many farmers are seriously thinkng of deroting much more attention to that promising industry.

\section{Turning Apples into Money.}

The apple tree begins to bear about the tenth year, and the productive life of a tree averages not less than fifty years.

The Superintendent of the Forest Fruit Growers' and Forwarding Association (Lambton County), an experienced man who is himself an apple grower, places the annual cost of maintaining an acre of bearing apple trees, including cultivation, manuring, spraying, etc., at $* \$ 25$ (£5), and the cost of harresting, including packing and pack-

$* \$ 4,86 . \mathrm{s} .=£ 1$. But for convenience the round figure, $\$ 5$, is often used in this pamphlet. ages, at $\$ 35$ (£ $\mathrm{i}$ ); a total of $\$ 60$ (£12). The average yield in 1907 of the orchards included in that Association was 60 barrels per acre, exclusive of windfalls, culls, etc. The Association marketed its product in England that year, obtaining $\$ 3.2 n$ (13s. 13/4 d.) per barrel. The price was considered a good one, but the yield was deemed very moderate. The year previous the same Association sold its crop to Great Britain at $\$ 2.50$ (10s. $3 \frac{\mathrm{I}}{2} \mathrm{~d}$.) per barrel for grade No. 1 , and $\$ 2$ (8s. $23 / 4$ d.) per barrel for No. 2 grade.

Year in and year out, well-cared-for orchards, where fruit is marketed properly, will net the grower $\$ 100$ (£20) per acre. The returns are occasionally much higher. "Some years ago," a grower reports, "our orchard of $31 / 2$ acres yielded $\$ 1,000$ (£206) worth of apples"; another that "an acre of Russets. King's and Baldwins produced $\$ 1,150$ (£236) of fruit."

\section{THROUGH THE FRUIT BELT OF ONTARIO.}

\section{Viewing the Promised Land.}

During the autumn of 1910 , with a view to determining at first hand the productiveness and possibilities of the Fruit Lands of Promise which compose so much of Ontario's vast territory, the Department of Agriculture 
commissioned an expert to travel the Province from end to end and report fully and accurately as to conditions. 'The result was eren mole encouraging than was anticipated. In practically every district visited, wherever fruit growing had been seriously attempted, the report of results was amazing.

All description, facts and figures here given are the result of first-liand information, every item being gathered "on the spot" from reliable and representative fruit growers. gardeners, managers of canneries, evaporators or other cuterprises related to this industry.

\section{How to Reach Ontario.}

Step aboard an Atlantic liner at one of the British ports. In six days you land at Quebec - the Gibraltar of Anerica - whose capture one hundred and fifty odd years ago made Canada a nation of British people. In a few hours after you take the train at Quebec you enter the eastern end of the Prorince of Ontario, and strike the first fruit belt-the home of the noted dessert apples, the Fameuse (Snow), and the McIntosh Red.

\section{Valley of St. Lawrence.}

Eastern Ontario possesses a great acreage of apple orchards, along and near the St. Lawrence River and on the farms extending back toward the height of land which separates the valley of the St. Lawrence from that of its tributary, the Ottawa. Here grow many of Canada's inost famous apples. The original MeIntosh Red tree, or rather its withered trunk-it was recently killed by a fire which burned the nearby building-still stands at Dundela. eight miles from Morrisburg. It was dug from the woods over one hundred year's ago, and now has thousands of descendants in all parts of Ontario. The neighboring fruit growers are erecting a monument as a testimonial to its worth.

\section{Some Striking Examples.}

Some idea of the profits of fruit growing in this section may be gathered from the examples of a few orchards: Ernest Farlinger, Morrisburg, sold the crop this year (1910), from one to one-third acres of orchard, containing 40 MeIntosh Red trees and three Wealthys, for $\$ 100$ (£80). Harold Jones, Maitland, has four acres of Fameuse, planted in 1881, which has for sixteen years given an average annual return of $\$ 200$ ( $£ 40$ ) per acre, the crop being sold one year for $\$ 1,310$ ( $£ 262$ ).

\section{Old Orchard Renews Youth.}

W. G. Robertson, of Iroquois, has an orchard of $31 / 2$ acres surrounding his buildings, in all 3 acres under trees. Of these 125 trees are in bearing, the remainder being young trees set out within the past few years. The average age of the bearing trees is 25 years, and the 
varieties grown are Snow or Fameuse, McIntosh Red, Russet and Ben Davis. Prior to 1900, when Mr. Robertson came to the place, the orchard had been neglected, but after being pruned and eared it soon became profitable. In 1908 it produced 112 barrels, which sold for $\$ 290$ (£58); in 1909 , 208 barrels sold for $\$ 516$ ( $£ 10 t$ ); in 1910, (estimated) 125 barrels sold at $\$ 3.50$ (14s. 5d.) per barrel. Each year the owner kept 12 barrels of apples for his own use.

\section{A Handsome Net Profit.}

John Harkness, Irena, has a six-acre orclard of Fanieuse and McIntosh Red, set out by himself in 1871 and 1872. The trees were grown from seedlings planted in 1867, and grafted in 1869 and 1870 . This orchard is very thoroughly sprayed each year. The returns for several years back are as follows: 1905,\$1,293 (£259); 1906. $\$ 1,233$ (£247) : 1907, \$1,720 (£314); 1908, \$948 $(£ 190) ; 1909, \$ 1,383$ ( $£ 27 \%$ ). In each case this is after paying freight and commission. The barrels are made on the premises. "Barrels and work," said Mr. Harkness, "arerage from $\$ 300$ to $\$ 400$ ( $£ 60$ to $£ 80$ ) a year." This means a net profit of $\$ 108$ to $\$ 220$ ( $£ 22$ to $£ 44$ ) an acre.

\section{The Price of Land.}

Land in this district along the river front is held at $\$ 100$ to $\$ 125$ (£20 to £25) an acre, while as one travels inland the price usually lowers. It should further be stated that located at Morrisburg is a district office of the Department of Agriculture, designed to assist the agricultural and fruit growing interests of the people of the counties of Dundas, Stormont and Glengarry. The St. Lawrence fruit belt extends from the eastern end of the Province to the city of Kingston. The product is shipped principally to the Liverpool nuarket and the Canadian West.

\section{The Fertile Ottawa Valley.}

Crossing from Prescott, on the St. Lawrence, northward, one enters the Ottawa Valley. The apple growing belt here extends from l'Orignal on the east to Pembroke on the west. The leading varieties are the Yellow Transparent, Duchess, Wealtlyy and McIntosh, and the cities of Ottawa and Montreal provide large local markets, and alone consume all the fruit grown in the district.

\section{What Single Trees Have Done.}

On the Central Experimental Farm, owned and operated by the Dominion Government just outside the city of Ottawa, records are kept of the rields of individual trees. For example, a Duchess tree, planted in 1888, has the following recold for seven consecutive years, ending 1910 , in bushels: $11,11,11,10,9,6.10$; that is, it produced never less than two barrels a year, and up to three and four. A MeIntosh Red at 12 years of age produced $4 \mathrm{I} / 2$ barrels: a McMalion White tree, of the same age, 


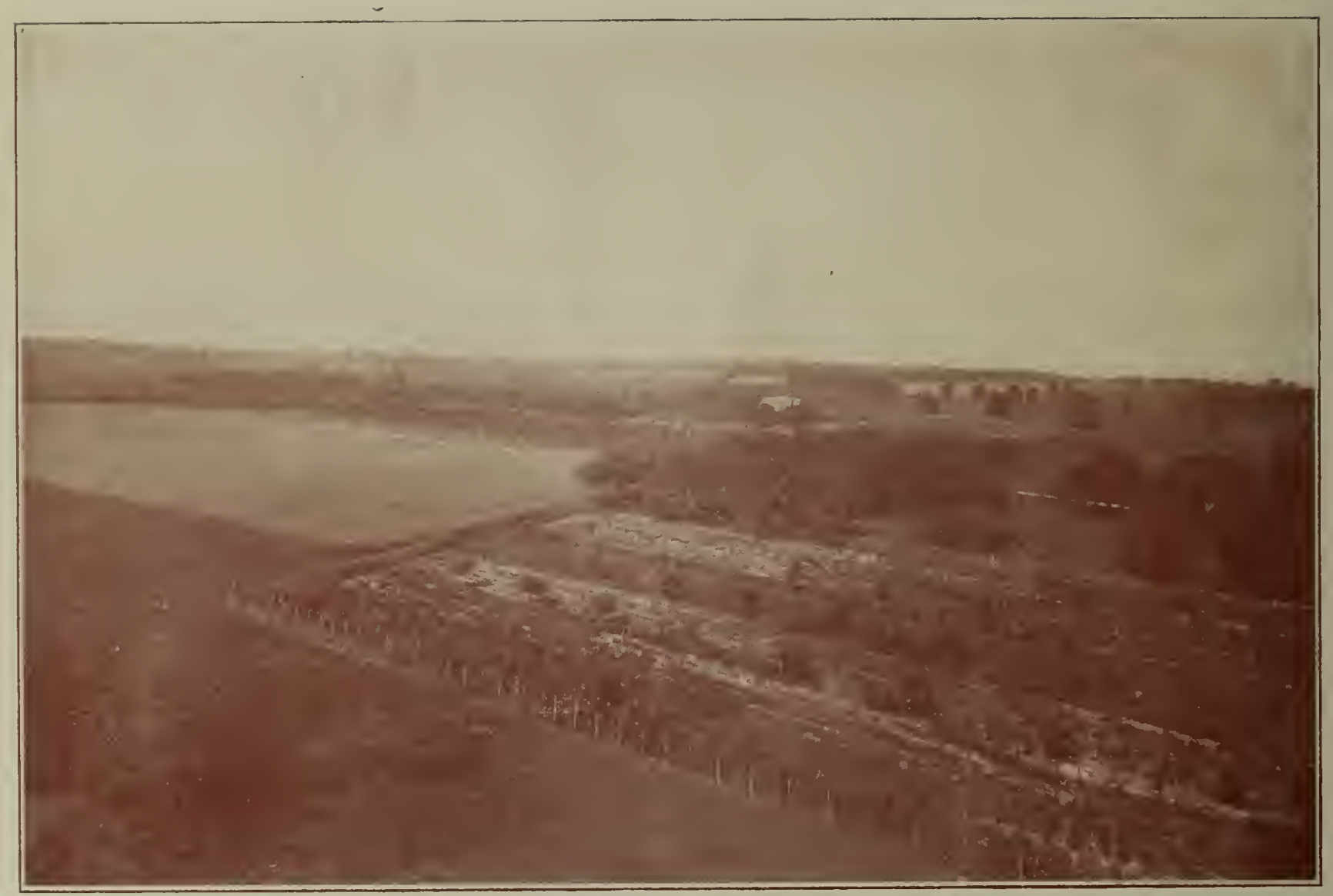

Fruit Farms. 
gave six barrels, while a Wealthy orchard, closely planted, in its tenth year, gave a net profit of $\$ 283.34$ (over $£ 5 \%$ ) per acre.

\section{Results from Market Gardening.}

In this section there are a number of residents who have built up splendid homes from market gardening, all beginning in a small way. One example is that of Peter Carstesen, a native of Germany, who, on coming to Ontario, first worked on some of the larger farms. Then he bought ten acres of hare land near Billing's Bridge at a

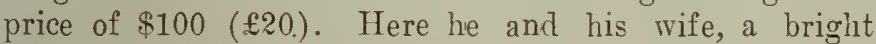
English woman, by their industrious efforts have built up a comfortable home. They have a fine, large brick house, large greenhouse, stables and storehouse, the property being free from any incumbrance, and worth to-day from $\$ 15,000$ to $\$ 20,000$ ( $\$ 3,000$ to $£ 1,000$ ). The annual sales from this small farm average $\$ 3,000$ ( $£ 600)$. The yearly labor bill for outside help does not exceed $\$ 150$ (£30).

\section{Productive County of Prince Edward.}

Prince Edward County is all but an island on the shore of Lake Ontario, being separated from the mainland by the Bay of Quinte, a long inlet. It is remarkably productive, the dairying and fruit canning industrics being carried on to great extent. Fruit growing of all kinds is carried on most successfully. The extent of the apple crop may be estimated from the fact that there are 15 apple craporators in the county, the largest having a capacity of 25,000 bushels a season, and the others from 30 to 60 per cent. of this. Some of the winter apple vields run at five barrels to the tree. Small fruits are also grown very successfully. A sample yield of cherries by C. A. Pettengill, Wellington, is worth noting. He owns a 12-year-old chelry orchard of two acres in extent. This year (1910) he sold 300 eleven quart baskets at 98 cents (about $4 \mathrm{~s}$ ) a basket. Last year his clop was 5,000 quarts.

\section{Lake Ontario Fruit Belt.}

Crossing the narrow neck of land which connects Prince Edward with the mainland, the town of Trenton is reached. From this town the apple shipments frequently reach 200,000 barrels a year, although the next shipping centre is only eght miles away. Westward through the counties of Northumberland, Durham and Ontario the apple belt extends back from the lake a distance of over 20 miles, and even beyond small fruits grow in profusion. Near Brighton the 20-acre orchard of Mr. Solomon, nearly all apples, has brought its owner as high as $\$ 5,000$ ( $£ 1,000$ ) in a single season. The 1909 crop was 1,190 barrels, while 1910 produced a $\$ 4,000$ ( $£ 800$ ) crop.

\section{Big Market at Toronto.}

Following through these apple orchards the traveller comes to the city of Toronto, capital of the Province, with 
a population of $4: 3,000$, and growing with rapid strides. It is one of the large local markets for fruits and vegetables. From the city an elcetric railway runs out a dis-

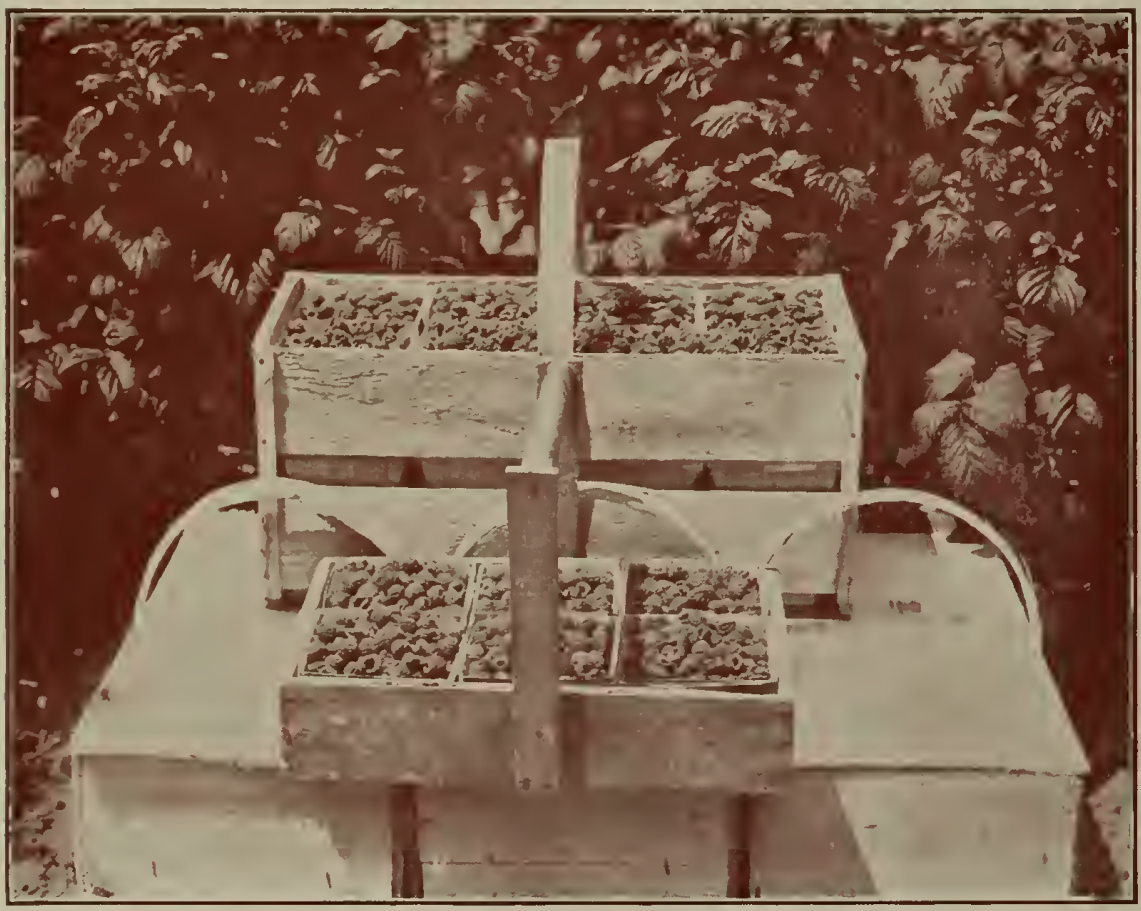

Packed Raspberries. tance of 12 miles to Port Credit; tapping a portion of the most fertile land.

The Hamilton Fruit Belt.

At Port Credit begins a new type of fruit country. The apple belt does not end, for apple orchards of both fall and winter varieties are found in considerable extent, and there is a large acreage of young orchards. But there is a strip of land along the lake to the city of Hamilton, extending two to three miles inland, which is chiefly sandy soil, and is peculiarly suited to the growing of small fruits ard vegetables. With easy access to large city markets this is one of the favored garden spots of Ontario.

\section{The Price of Productive Land.}

The development of this section dates back no further than ten or fifteen years. Prior to that time it was made up of farms of 100 to 220 acres, given to dairying and the growing of general farm crops. Now the rule is 10,15 and 25 acre holdings, and most 
of the owners of these small farms are making as much as their predecessors did off ten times the acreage. The usual price quoted for land here is $\$ 300$ to $\$ 400$ ( $£ 60$ to

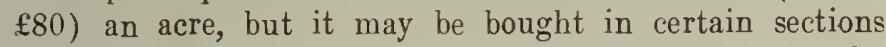
for less. But at these prices, or even higher, it is a profitable investment.

\section{Man and Boy Reap Big Results.}

Mr. W. M. Shaver, Lorne Park, has $131 / 2$ acres of fruit farm and garden near Port Credit, and 5 acres of orchard and garden at Lorne Park, where he lives. He and his son, who is just a young lad, do all the work on the place, except the picling of the fruit. Five acres is in pasture land, yet the net returns are $\$ 1,300$ to $\$ 1,400$ ( $£ 260$ to $£ 280$ ) a year. Off $13 / 4$ acres of strawberries 19,000 quarts were picked this year, realizing $\$ 900$ ( $£ 180$ ) clear of expense and commission for selling; $2 \mathrm{I} / 2$ acles of raspberries produced $\$ 250$ ( $£ 50)$ per acre clear of expenses of picking, etc.; $2 \mathrm{I} / 2$ acres of blackberries (thimbleberries) averaged also $\$ 250(£ 50)$ per acre; 200 bushes of red currants, set out two years ago, gave 480 quarts. There is a fine voung olchard of Duchess and Snow apples, with cucumbers and other vegetables grown between the trees until they come into bearing. Mr. Shaver does not pretend that he is working his farm to its capacity, but says that he would be quite ready to take fire acres and make a good living for his family by more intensive cultivation.

\section{From Hired Man to Owner.}

It is interesting and inspiring to learn that many of the men who have built up fine homes in the Clarkson district are Englishmen who came to Ontario with nothing but their labor to depend upon. James Lightfoot, a native of Cumberland, England, now owns 43 acres of the original Orr farm on which he worked as a hired laborer for five years. Ten years ago he started up for himself with a capital of $\$ 500(£ 100)$, the savings from his labor, buying 10 acres at $\$ 140$ an acre. Since then he has not only paid for the entire acreage he holds, but has built and paid for a fine $\$ 2,000$ ( $\$ 400$ ) brick house, good stable, fruit house and other buildings. His produce consists of strawberries, raspberries, blackberries. potatoes, cucumbers, corn and other vegetables. Ten acres of his holding is still woodland and a large part of it is used for pasture, the fruit and vegetable garden being only about 10 acres. In 1909 he had in the bank as his season's profit, after paying all expenses, $\$ 2,700$ (£540), while the previous year he put away $\$ 3,500$ $(£ 700)$ in profits.

\section{Accomplished Much in Seven Years.}

Arthur J. Cox, a neighbor, has 12 acres of the original Orr farm. He came to Ontario from Bedfordshire, England, and rorked as a farm laborer. Seven years ago he began here with $\$ 1,000$ ( $£ 200$ ) capital, paying $\$ 1+0$ 


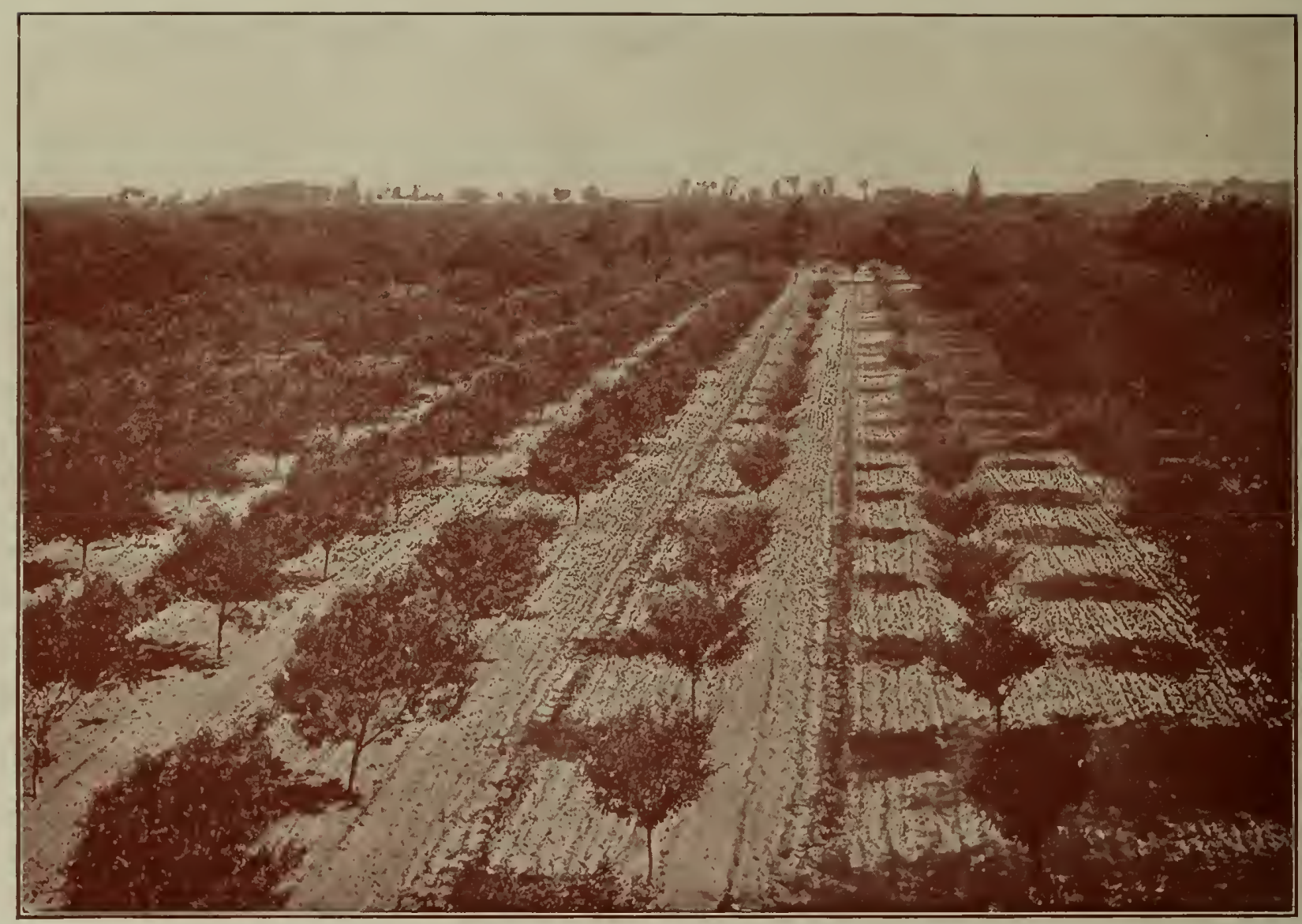

Peach Orchard. 
(£28) an acre for his land. He built a brick house and stable, and within four years had everything paid for. Since then he has enlarged his house, putting in hot water heating and all city conveniences, at a total outlay of $\$ 3,000$ ( $\$ 600)$. The present season's profits will pay the balance on these improvements. His sales for 1909 were $\$ 2,000$ ( $£ 100$ ), and net profits $\$ 1,000$ ( $£ 200$ ).

\section{Started Without Anything.}

On another side of the Orr farm is. Dennis Herridge, who caine from Berkshire, England, seven years ago and worked four years for Andrew Orr, the original owner. Then he bought 13 acres from his employer, married a bright Canadian girl, and set up house for himself. He is doing well, although, as he said, when he came to Ontario he hadn't money enough to take him back to England if he wanted to go. For the first year, he says, he had to take small wages, because he was inexperienced. but after that wages were gord and he saved enough to give him a start.

\section{Another Man Who Succeeded.}

About a mile from Oakville railmay station is the neat little farm and home of Thomas Breen. He has 10 acres of land, on which he grows cherries, plunis, pears, strawberries, blackberries, raspberries and regetables. $\mathrm{He}$ is a native of Gloucestershire. Fifteen years ago he started here on the bare land, paying $\$ 115$ ( $€ 23$ ) an acre. His capital was $\$ 200$ ( $£ 40$ ), his savings as a farm laborer in the ricinity. From his little farm, which he now owns free of debt, he makes a comfortable livins, selling $\$ 800$ to $\$ 850$ ( $\$ 160$ to $£ 170$ ) worth of produce yearly.

\section{Two More Land Owners.}

His next neighbor, William Bartlett, is a native of Warwickshire. Eleven years ago he bought 15 acres, commencing with $\$ 900$ ( $£ 180)$ saved frum his earnings as a laborer on neighboring fruit farms. He grows chiefly small fruits and garden truck. In three years he cleared off a mortgage of $\$ 600 \quad(£ 120)$. His house and barn are valued at $\$ 1,000$ (£200). About a mile down the electric road is one of the prettiest 15 acre farms in the district. It is owned by Robert Burton, a native of Norfolk, and is a portion which he bought seventeen years ago off the farm on which he worked as a laborer. He now has a beautiful home, the entire place being set out in small fruits. Of regetables he grows only enough for his own use.

\section{The Niagara Fruit Belt.}

The city of Hamilton, which lies at the head of Burlington Bay, furnishes a splendid local market for fruit. Back of the city lies the "Mountain," which is more properly a tableland, ending in a steep cliff-like ridge, which crosses the country to Niagara Falls. From the base of the ridge a level floor runs to the shore of Lake 
Ontario-this was once a lake bed, and is now the farfamed "peacl belt" of Ontario. Throughout this whole district fruits of all kinds flourish to a remarkable extent.

\section{Where Fruit Land is in Demand.}

The village of Grimsby, in this district, is the central office of the Ontario and Western Shipping Association, which has 140 fruit growers as members and which operates from Beamsville to Stoney Creek, shipping fruit to all parts of Canada. This is where the famous peach land is located-where owners ask $\$ 1,000$ (£200) an acre and upwards for bare land, and get it. And the buyers are satisfied with it at that price.

\section{What Ten Acres has Produced.}

As an example of the returns from the fruit farms in this district the record of Hamilton Fleming for his 10 acre farm for the year $\mathbf{1 9 0 9}$ may be cited. His net profits from the sale of his produce were: Strawberries, $\$ 121.22$ (£25); cherries, $\$ 70.50$ (£14); raspberries, $\$ 389.89$ (£78); currants, $\$ 15$ (£3) ; potatoes, $\$ 30$ (£6); peaches, $\$ 2,478.40$ ( $£ 495)$; making a total of $\$ 3,105.01$ (£621). The peach trees are about 14 years of age. One heavily laden tree had 21 baskets.

\section{Could do it Over Again.}

James Stephen, whose farm consists of 21 acres of the original Walker estate, came to Ontario from Caithness,
Scotland, and worked as a laborer on fruit farms between Beamsville and Winona. Fiftcen years ago he rented the place which he now owns, paying \$226 (£45) yearly rental, and "making money at that," he says. After three years he bought the farm, paying $\$ 1,000$ ( $£ 200$ ) down. He now owns it clear, and has also 14 acres of land near by partly paid for. On this 21 acres he has two fine liouses, a large stable and a greenhouse. He keeps 2 cows, 3 horses, and raises several hogs. He grows peaches, cherries, pears and raspberries. He sold $\$ 2,750$ (£550) worth of fruit off his 21-acre farm last year. Mr. Stephen believes that a number of the neighboring farms could be worked to advantage in smaller holdings, and that the Province could easily support, by closer cultivation, five times the number of people it has now. "Give me $\$ 300$ to $\$ 400$ ( $£ 60$ to $£ 80$ ) and the land," he remarked, "and I will do over again what I have done here."

\section{A $\mathrm{Co}_{0}=$ operative Association.}

The city of St. Catharines, situated in the Niagara district, is a very large shipping centre for fruits and vegetables. The St. Catharines Cold Storage Company, Limited, which has been in operation for 12 years, is made up of a number of local fruit growers combined into a co-operative association. Produce is shipped in carload lots, and the shippers are thus enabled to get cheaper freight rates and quicker service. The company's manager gives liis time to the shipping and selling of the produce, 


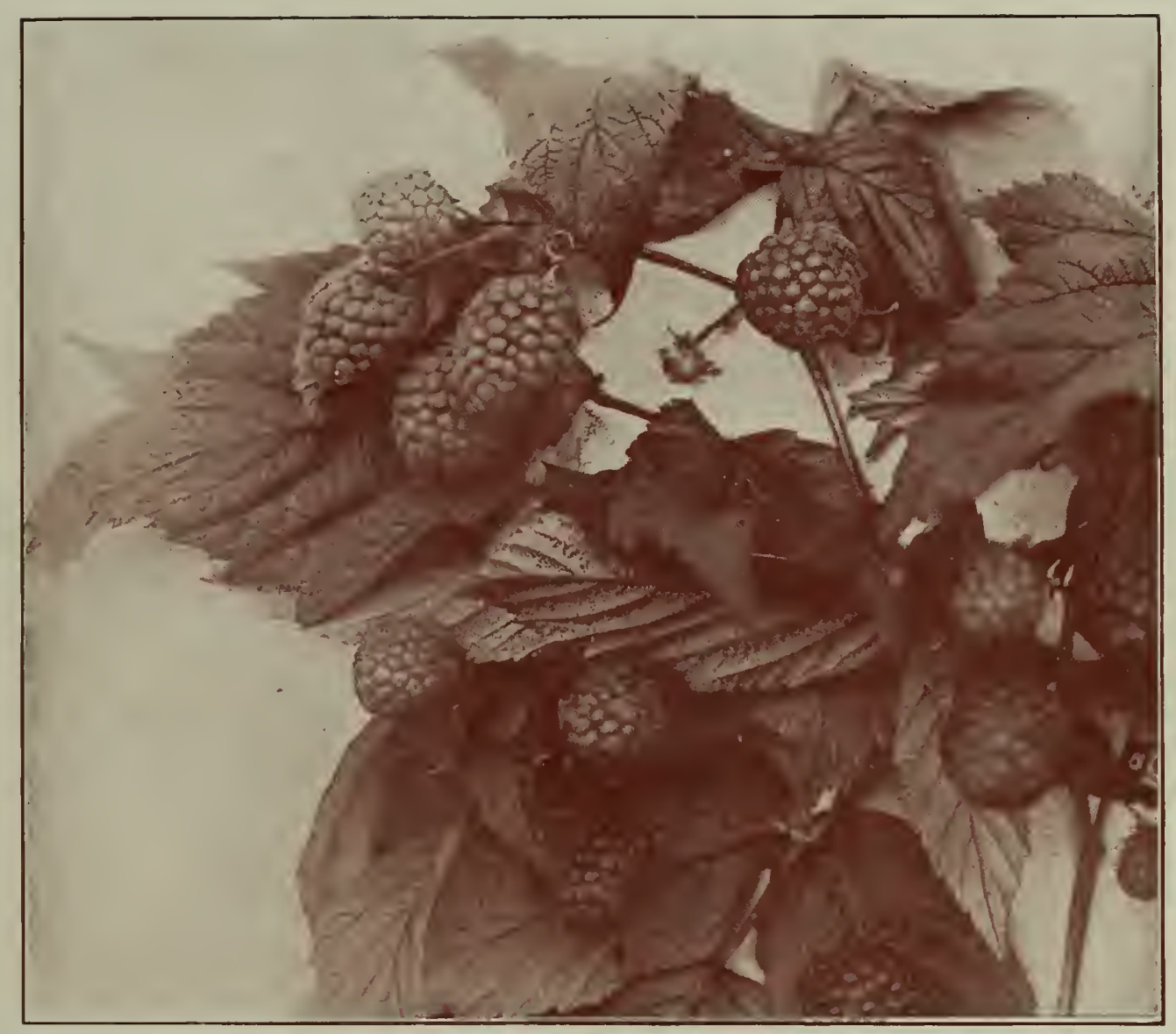

Cuthbert Raspberries. 
so that it is marketed to the best adrantage and for the highest prices. The fruit growers belonging to the association buy their supplies in large quantities, and thms ellect considerable saving. A charge of $2 \%$ is made to all persons whose stuff is handled by the association. After expenses are paid a rebate is made to those who are shareholders in the association.

\section{The District of Lake Erie.}

The I ake Erie district is a veritable home of successful fruit growing. In the county of Norfolk, and particularly in the neighborhood of the town of Simcoe, beside the bearing orchards, are hundreds upon hundreds of roung trees, apple. cherry, pear, peach and plum, secn on the different farms. Near St. Williams, not far from the shore of Ialie Erie, the Ontario Department of Agriculture has a forestry farm. part of which is being set out with pines, and part used for growing a stock of all kinds of Canadian trees, which are supplied at the cost of carriage to any one in the Province applying for them to plant upon his own premises. The Department has also a District Office at Simcoe.

\section{The Romance of Fruit Growing.}

There is more than one romance connected with the awakening of fruit growing in the county of Norfolk. One orchard of too trees is pointed out as having paid for the rest of the farm (160 acres) in a few years, the purchaser making but a small payment down in 1905, and clearing off the rest from the produce of the orchard. On another farm is a 40 -acre orchard, which was planted 25 years ago by a man whom his neighbors dubbed as crazy for so doing. 'The farm has changed hands within the last few years at increasing prices, $\$ 10,000 \quad(£ 2,000)$, and

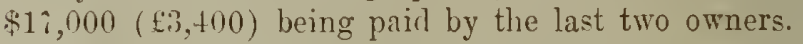

\section{Returns More Than Doubled.}

Peach growing is on the increase here. Returns from bearing orchards warrant this increase. Messrs. Smith Brothers, of Townsend township, have $3 t$ peach trees set out along with apple trees in a small orcharl. The fourth year, after planting, these trees gave a $\$ 60$ (£12) crop. while the filth year they realized $\$ 130$ ( $₫ 26)$ worth, the returns more than doubling in a rear. Fight apple trecs in the same orchard-Talmon, Spy, King and Russetyielded 21 barrels last year.

Mr. George Heath, a neighbor, has a peach orchard set out in 1900, which gave as the season's crop between $\$ 1,300$ to $\$ 1,400$ ( $£ 260$ to $£ 2 s 0$ ) from 249 trees; one tree producing $\$ \$ .50$ (£1. 1 s. $11 \frac{1}{4}$ d.) worth of peaches. He has also a plot of $11-3$ acres of blackberries, giving as their first crop this year $\$ 600 \quad(£ 120)$. Strawberries on this farm arcraged $\$ 325$ to $\$ 3 \% 5$ ( $£ 65$ to $£ \% 5$ ) per acre in the last two years. 


\section{Productive Land at Cheap Price.}

I four acre orchard of winter varieties at Walsh station, planted 15 years, but not given any attention, was bought in the spring of 1909 by Dr. IVilliam Burt, of Simcoe. It was cultivated and cared for, and last year

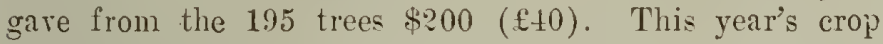
(not all packed at the time of writing) is estimated at 400 barrels. An orchard of two acres on the farm of Alfred Roberts returnel from 39 trees of winter variety 130 barrels in 1908: 150 in 1909, while the estimate for 1910 is at least 100 .

The price of land licre is $\$ 30$ ( $£(6)$ an acre upwards. The county has quite a supply of natural gas which is piped to the towns and rillages and the farm louses, and is used for lighting and heating. Rural telephones extend all over the county.

\section{Other Good Orchard Land.}

The village of Sparta, in Flgin county, is already known in England for the firmness and dependable quality of its apples. Along the sandy and gravel ridge to the north of this village grow splendid crops of peaches and small fruits. Cherries and plums also do excedingly well. Near St. Thomas, the county seat, is a cherry orchard of 400 trees, and a plum orchard of like number, the fruit of which the grower puts up in his private can- nery and sells in the North-West market. General farming and stock-raising prevails in this section, but every farm has its apple orchard.

\section{A Peninsula of Productiveness.}

The counties of Essex, Kent and Lambton, which constitute the south-western peninsula of the Province, form a wide level floor of rich soil, once an ancient lake bed. Corn is gromn rely extensively, the grain to make food for $\operatorname{logs}$-which are raised here in great numbers-and the corn stalks to make fodder for cattle. Along the valley of the Thames River is a good section of orchard land. Early apples are a popular crop and peaches grow successfully. Electric railways, mural telephones and rural mail delivery are features of this part of the Province.

1

\section{A Veritable Vegetable Garden.}

Around Leamington is the vegetable garden of Ontario. Lying farthest south, and almost completely surrounded by water, this section can produce very early outdoor vegetables. Strambcries ripen here about two weeks earlier than in other parts of the Province. Tomatoes planted in the open on May 25th have produced ripe fruit on June 19th, while regular shipping of this tomato crop starts on July 1st. Large quantities of early regetables are raised in greenhouses. 


\section{Came Back to Productive Province.}

Facts speak for themselves. Mr. W. W. Hilborn has a new greenhouse, built last year at a cost of $\$ 6,000$ $(£ 1,200)$. Mr. Hilborn spent some time in California, but came back to Ontario because, he says, "I can makc more money in fruit-growing and gardening here."

Mr. R. H. Ellis, gardener, sold this year (1910) from two greenhouses, 186 by 20 feet and 100 by 20 feet, over $\$ 1,000$ ( $£ 200$ ) worth of early tomatoes. His cucumber crop, from a greenhouse 60 by 100 fect, from the midilc of May to the middle of July, brought him $\$ 1,200$ (£240).

\section{What was Done on Small Farm.}

Mr. E. E. Adams, a merchant, began fruit farming and gardening 11 years ago, and has made good profits on a 25 -acre farm. His last year's sales totalled $\$+, 80 \tau$ (£962). Muskmelons, cabbage, was beans, pcppers, onions and other regetables are grown. These average $\$ 200(£ 40)$ an acre; some crops and some seasons running higher. Peaches, pears and plums are the principal fruits, while tobacco is one of the staple crops of Esscr and Kent counties. This crop brings from $\$ 2.50$ to $\$ 300$ (£50 to $£ 60$ ) an acre.

\section{Lake Huron District.}

The county of Lambton produces a large quantity of apples of both autumn and winter raricties. There are six co-operative Fruit Associations; at Forest, Watford, Alvinston, Wyoming and Thedford. The town of Forest is the largest shipping centre. Five miles north-west of Forest, on the shore of Lake Huron, is one of Lambton's most successful orchards, that of Johnson Brothers. In all about $\% 0$ acres of this farm is planted in apples, plums and peaches. The apple trees range in age from 65 years to this year's planting. There is a 12-acre plot of three year old peaches and 15 acres of bearing plums.

\section{The Value of Scientific Treatment.}

'This orchard demonstrates strongly the value of scientific treatment. Under the old method of letting trees grow without attention, the yearly product was about 200 to 300 barrels. Last year 2,300 barrels of apples were cxported and 2,000 barrels made up into the evaporated article, which represented a gross return of over $\$ 10,000$ $(£ 2,000)$ from 35 acres of bearing orchard. In this orchard is a Baldwin tree with a fondness for making big records. Its last year's crop was 20 barrels, but in 1908 it exceeded this, yielding 28 barrels of apples, mostly of the first grade, selling at $\$ 84$ ( $£ 17)$.

\section{Fruit Industry is Developing.}

Plums also do well, the 15-acre plot making this year over $\$ 1,200$ (£240) profit. while near Forest one orchard of $3,00 n$ peacl trees was planted this spring and has done 
so well that the owner intends planting out 2,000 more next year. It is said that orders are now in the hands of nurserymen for over 20,000 peach trees for next spring's planting within a radius of three to four miles of Forest. Throughout the county it is estimated that 200,000 treespeaches, apples and plums-will be planted next spring.

\section{Chance For the Tenant.}

Renting orchards is a profitable industry in this county. A seven-acre orchard taken on shares, the owner taking one-third of the gross returns, gave as rental for the land $\$ 163.76$ (£33) to the owner and a net profit of $\$ 245.64(£ 49)$ to the tenant. The total cost of cultivating, pruning, scraping trees, drawing brush, spraying trees, picking and packing the apples was $\$ i 1.88$ (£14). Another orchard of ten acres, which liad been leased for five ycars at $\$ 75$ (£15) per year, was leased for another term last year at the expiration of the first lease, at $\$ 350$ ( $£ 70$ ) yearly rental. This increase is a pretty reliable indication that the enterprisc was a success.

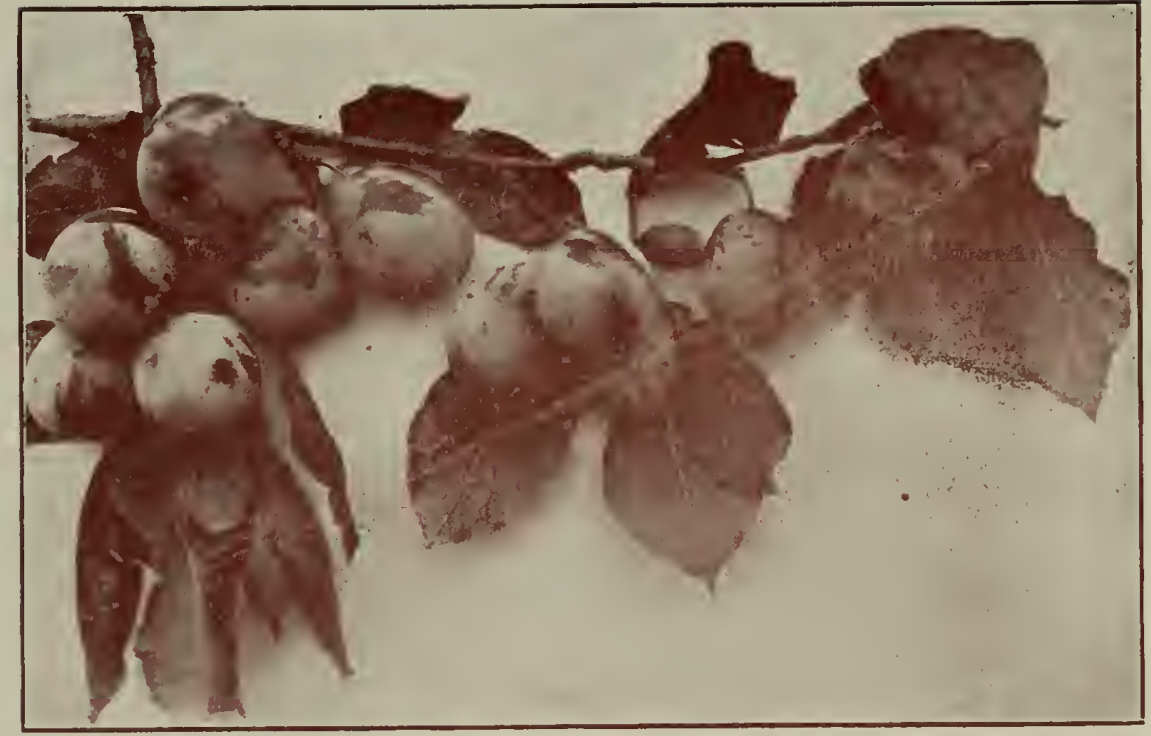

Bradshaw Plums.

Many Orchards.

The county of Huron has a large acreage of apple orchards, every farm having at least a few acres, and some as high as 75 acres. Mr. R. R. S.loan, Porter's Hill, has a 60 -acre orchard, consisting of two acres 25 years 
planted; t5 acres 18 years planted, and 13 acres two years out. Along the lake from Bayfield to Goderich the farms have very large orchards, a number of which are quite young. A ten-acre olchard of winter apples at Blyth produced a crop of 900 barrels in $190 \%$ and 800 barrels in 1909. Mrr. A. Beatty's orchard, near Goderich (10 acres, not rely thoroughly cultivated), gives $\$ 400$ ( $£ S 0$ ) to $\$ 750(£ 150)$ as the value of its crop for some years back. l'lums also grow well in this district.

\section{What a Poor Man has Accomplished.}

Bruce county has much the same fruit conditions. Peaches are grown here in the vicinity of Port Elgin. At Walkerton is a splendid example of a successful small farm, showing that the possibilities of small fruit growing and gardening are not restricted to any particular part of the Province. Here, close to the town, Mr. A. E. sherrington, a Canadian farmer, broken down in health from the care of a heavy stock farm, began 19 years ago on a small plot of seren acres. He has gradually added to this until he now has $2 t$ acres. He has five acres of apple trees 35 years old, $21 / 2$ acres (an experimental plot) one to ten years old; two acres of plums and cherrie: Gooseberries and currants are grown as "fillers" in the joung apple orchard. This year he had two acres of strawberries, $21 / 4$ acres of raspberries, $21 / 4$ acres of tomatoes, 1 acre of potatoes, besides a plnt of alfalfa and other crops. His orchard has returned $\$ ; 00$ to $\$ 800$ ( $\$ 140$ to
$1160)$ a year for the last ten years. Other crops give gross returns of about $\$ 250(£ 50)$ an acre. Nearly all of this produce is sold in Walkerton and the ncighboring towns. Farm property liere runs in price from $\$ 60$ to $\$ \$ 0$ ( $£ 12$

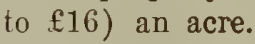

\section{Georgian Bay Fruit Belt.}

'The Georgian Bay fruit bclt skirts the shore of the Georgian Bay and follows the vallcys inland a distance of twenty miles and more. Winter apples are the principal fruit crop, but large quantities of plums and pears are shipped from Owen Sound, which is the gateway to the upper lake traffic. There is a very successful cooperative association in this district, which owns a largc storage plant, with a capacity of 12,000 barrels. All fruit is packed at the shipping house, and thus a uniform grading is secured. The association has a paid manager who superintends the packing, selling and shipping. Is a result of this co-operation the nembers secure a much higher price for their fruit than those who sell to the apple buyer. Becides this they have the picking done for them at actual cost by the association. This association also owns a cooperage and an apple eraporating plant.

\section{Where Growers are Organized.}

The district is a most fertile one. All the farms have apple orchards ranging from 5 to 25 acres in extent. Pears, plums, raspberries and strawberries are grown in 
the ricinity of Meaford, and also a few peaches. The small fruits are teamed in quantities to the local markets. Gooseberries, currants and grapes thrive, and tomatoes, peas, beans and other regretables are grown to supply the local canning factories. 'The village of Thornbury is the headquarters and shipping point of the "Georgian Bay Fruit Growers, Limited," which has a membership upwards of 200 and owns a $\$ 10,000$ storage plant, with a capacity of 20,000 barrels. Last year 45,784 barrels of apples were shipped from this point and 9,233 used by the eraporators.

\section{Results in Six Orchards.}

The Thormbury section merges into the Collingwood district. Apples are still the staple crop, but plums, pears, peaches and grapes are extensively grown. The Ontario Department of Agriculture have a clistrict office in Collingwood and. through its representatives, this year took charge of six orchards in Nottawasaga township. These were carefully sprayed and gave good results. Red Astrachan trees in one orchard produced $\$ 6$ to $\$ 8$ ( $€ 1.4 \mathrm{~s} .8 \mathrm{~d}$. to $£ 1.12 s .10 \mathrm{r} / 2 \mathrm{~d}$.) a trec. Duchess apples sold at $\$ 2.50$ (10s. 31/2 d.) a barrel, netting the owner $\$ 1.80$ ( $\% \mathrm{~s}^{4} \% \mathrm{~d}$.), an average net profit of $\$ 7$ ( $£ 1.8 \mathrm{~s} .91 / 4 \mathrm{~d}$.) a trec.

\section{What a Woman has Accomplished.}

The experience of Mrs. D. T. $\mathrm{N}$. Mitchell is an eyeopener to Ontario's possibilities. She has a fivc-acre garden near Collingrood. It was bought 1 ? years ago for
$\$ 800$ ( $£ 160$ ) and improvements made. This little farm has brought its owner returns as high as $\$ 1,000$ ( $£ 200$ ) a year, and never below $\$ 500$ (£100). Strawberries yielded $\$ 340$ ( $£(i 8)$ from a plot of less than an acre, and tomatoes $\$ 200$ ( $£ \neq 0$ ) from a plot of equal size. Onetentl of an acre of onions brought $\$ 35$ ( $£ \tau$ ), and two acres of cabbages $\$ 100(£ 20)$. She kecps one horse to do the work and pays $\$ 150$ ( $£ 30$ ) for the season to a hired man. Her property is now worth $\$ 3,000$ ( $£ 600$ ). Mrs. Mitchell says of her work: "This garden has paid me well, botl financially and physically. I feel much better when working out in my garden in the summer time than when looking ilfter my town house in the winter. My boys, as they were growing up, have always bcen a great help to me. 'This has been a good thing for them, since it kept them oft the streets and gare them the exercise required." Land values throughout this district vary from $\$ 40$ to $\$ 100$ ( $\& 8$ to $(? 0)$ an acre.

\section{The Inland Counties.}

Westward of Lake Ontario are sercral counties lying inland. Of these the comntics of Brant, Oxford, and Middleser, and the southern portion of Waterloo and Perth form an extension of the apple belt, which runs along the north shore of Lake Ontario. Although in these counties the nain agricultural industries are dairying, mixed farming and stock raising, there is a large acreage of orchards, winter apples doing particularly well and the Fameuse being a good producer. 


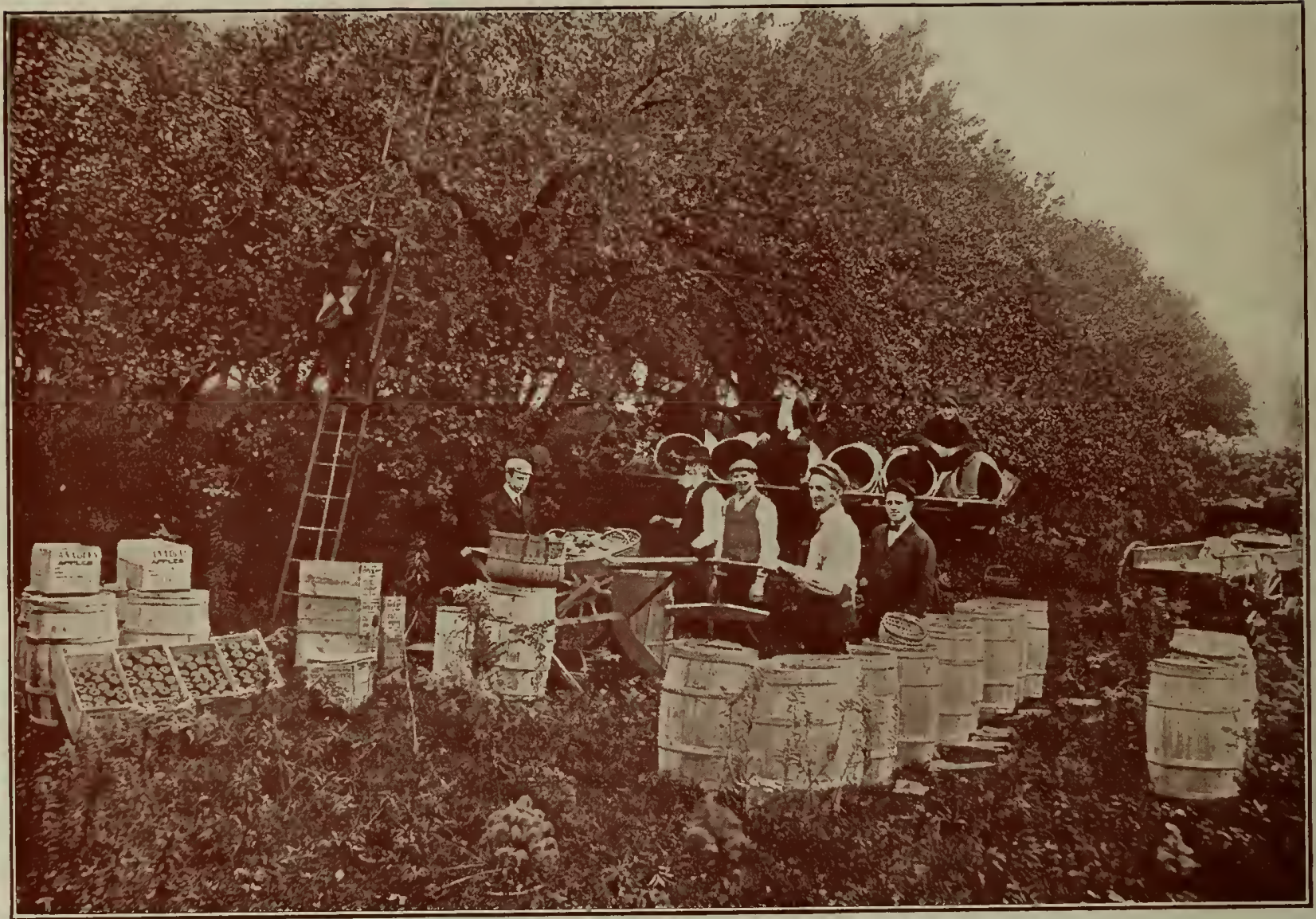




\section{Fruit for the Festival of Empire Exhibition.}

The Northern Spy, which is probably the most popular winter apple, does particularly well in this district, bearing witl great regularity and producing fruit of high color and fine flavor. Many orchards in the vicinity of the town of Ingersoll contain a large proportion of trees of this variety.

The Dairy and Cold Storage Commissioner for Canada, Mr. J. A. Ruddick, on behalf of the Dominion Government secured from the orchards of Mr. J. C. Harris, Ingersoll, a carload of apples of assonted varieties for the Dominion Exhibit at the Festival of Empire Exhibition to be held in London, England, in 1911.

\section{Some Good Records Made.}

From some of the orchards in this vicinity the following records were secured: Mr. W. Hayes, 175 trees, Spies, Kings and Greenings, yearly crop from 350 to 600 barrels; Mr. M. J. Clear, 11/, acres, 55 trees, winter varieties, 100 to 135 barrels, average for 6 years 108 barrels; Mr. Wm. Batten, 115 trees, winter varieties, four consecutive years ending 1910, 600 barrels, 100 barrels, 200 barrels, 220 barrels; Mr. George Gregg, 2 acres, average for a number of years, 75 to 100 barrels per acre; Mr. Colin Tait, 26 trees, Spy and Greening, 1910 crop sold for $\$ 180$ ( $£ 36$ ); Mr. Harry Sage from 26 trees Fameuse this year, 102 barrels; Mr. Win. Nutt, Zenda, 7 -acre orchard, crup this year sold for $\$ 1,400$ ( $£ 280$ ) and has also a large producing plum orchard.

\section{Lake Simcoe Fruit Belt.}

Around the southern end of Lake Simcoe are a number of large apple orchards, both autumn and winter apples doing well. Pears, plums, and cherries are grown successfully, but in smaller quantities. Near Sutton, Messrs. Silver and Sons have an orchard of 600 trees, 35 years old, which has been a good producer. From 540 of these winter variety trees, over 900 barrels were sold in 1909, bringing $\$ 4.25$ ( $17 \mathrm{~s} .63 / 4 \mathrm{~d}$.) per barrel in the Western market. Strawberries, raspberries and other small fruits grow well in this district and find a good market in the summer tourist resorts along the lake. Land here is worth $\$ 70$ to $\$ 100$ ( $£ 14$ to $£ 20$ ) an acre, including buildings.

A plot of strawberies in a favorable location yielded at the rate of $\$ 720 \quad(£ 114)$ an acre; raspberries brought $\$ 450(£ 90)$ an acre; currants, gooseberries and blackberries yield $\$ 250$ to $\$ 350$ ( $£ 50$ to $£ 70$ ) an acre.

\section{The New North Lands.}

The agricultural industries of the newly opened up northern portion of the Province are yet in their infancy, so that it is not yet possible to gauge the results in that region. Good apples are grown on St. Joseph's Island and 
other places ncar Sault Ste. Marie. Wild fruits, such as raspbcries, currants, cranberries, etc., grow in abundance, and small fruits have been grown successfully where cultivated. Potatoes, corn, bcans, tomatoes, and all kinds of regetables do well in this district.

\section{PEACHES.}

\section{How Peaches Pay.}

Peach growing has great attractions in Ontario, both from a financial and aesthetic point of view. The trecs begin to bear at four years, and in the hands of the carcful grower, four crops out of five may safely be counter upon. This has been greatly exceeded at iimes under favorable conditions and circumstances. There is an ever-enlarging market opening up for peaches, and the future will show a continual increase in the acreage deroted to this fruit.

\section{The Ideal Peach Soil.}

The idcal peach soil is a sandy loam with a gravel or clay subsoil at $2 \frac{1}{2}$ to 4 feet. Soil of this character is of very uneven distribution. As a rule it will not be found in the proportion of more than twenty acres on any hundred acre farm. Hence, land of this class is high in price, ranging from $\$ 200$ ( $£ 40$ ) to $\$ 300$ ( $£ 60$ ) per acre unplanted, and even higher in some sections. There are, however, growers who are securing excellent results on the hearior types of soil, and it remains to be seen whether, with underdraining, such soils could not be succcssfully planted to peaches.

\section{The Comments of Growers.}

"Peach culture has proved a profitable business with me, and I am planting more orchards every season."

"The business requires personal attention from start to finish, and any one with push and brains can make it pay."

Such are the comments of Ontario growers who have had results. Peaches bear at four rears, and will continue a profitable yield till alout the fifteenth year. One hundred trees are planted to the acre.

\section{What has Been Accomplished.}

The following figurcs arc those of a grower living near Queenstown, on the Niagara River, who specializes on peaches. The average orchard may not always have a yield equal to the figures he has given, but they show what can be done by industry and enterprise.

\section{The Cost.}

Annual cost per acre of bearing trees:

Spraying, \$5; manuring, $\$ 10$; pruning, $\$ \tau$; cultivating, $\$ 6 \ldots \ldots \ldots \$ 2800$

Picking, \$15; packing, \$8; packages, $\$ 30 \ldots \ldots \ldots \ldots \ldots \ldots \ldots \ldots \ldots \ldots$ Hauling to station (depending somewhat on location) $\ldots \ldots \ldots \ldots \ldots, 500$

Total cost

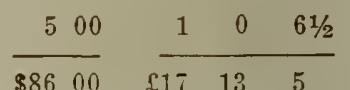




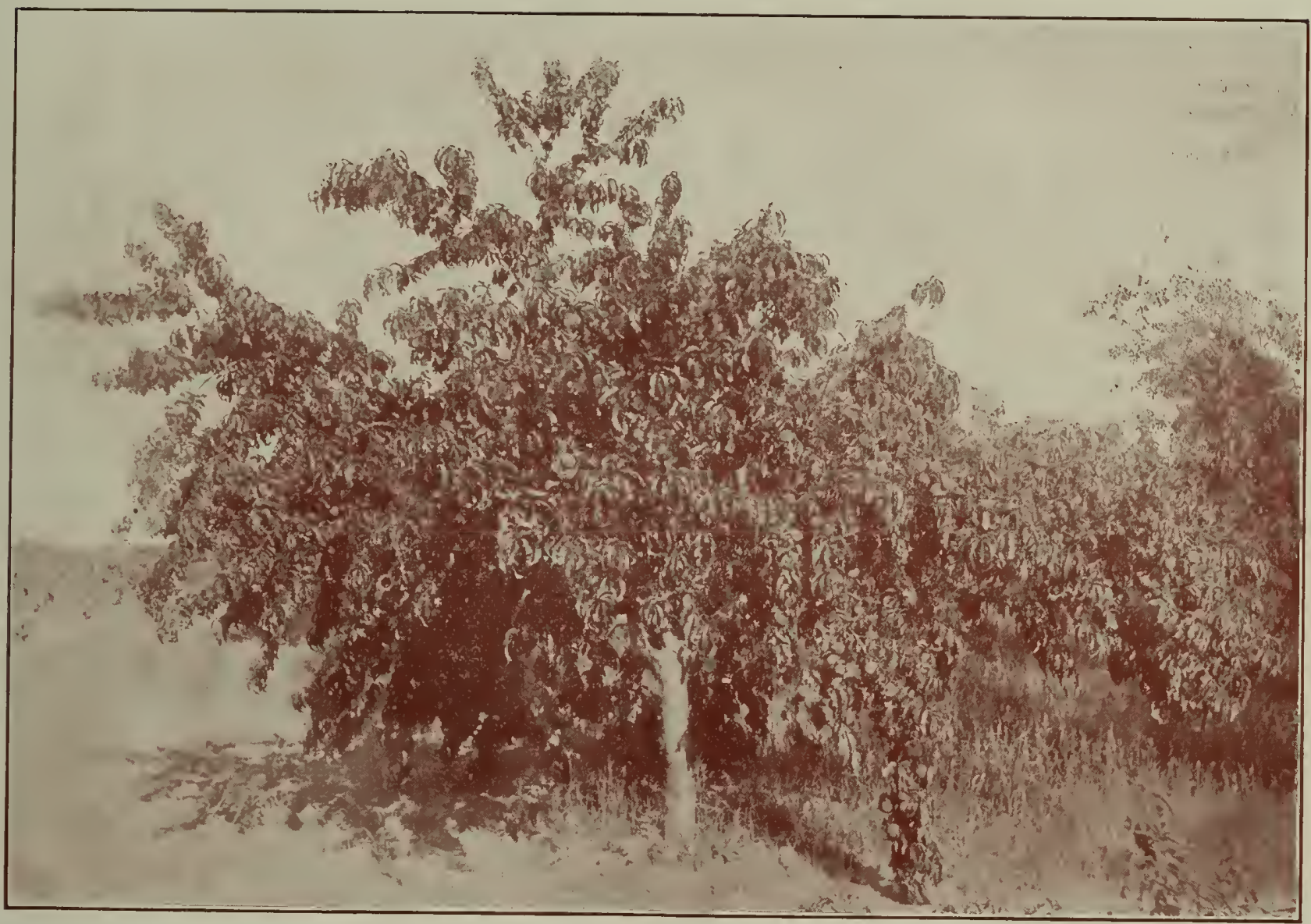

Peach Tree, 6 Years Old, Yielding 17 Baskets of 11 Quarts Each. 
700 baskets (11 quarts) at $50 \mathrm{c} \ldots \ldots . \$ 35000$ Less the expenditure........... 8600 Total net profit per acre....\$26400

\begin{tabular}{rrc} 
\& & s. & d. \\
11 & 18 & $41 / 4$ \\
15 & 13 & 5 \\
\hline 54 & 4 & $111 / 4$
\end{tabular}

\section{PEARS:}

\section{Profits on Pears.}

'T'he pear is not only in great demand as fresh fruit, but is one of the staple products for the fruit-cahning industry. The figures of a Burlington grower are here submitted, the estimate of yield being a very conservative one.

\section{THE Cost.}

Annual cost per acre of bearing trees, 100 trees to the acre:

Cultivation, $\$ 5$; manuring, $\$ 5 ;$ pruning, $\$ 4 ;$ spraying, $\$ 6 \ldots \ldots \ldots \ldots \$ 2000$ Picking, grading and hauling to railway station ............. 1400 Packages..$\ldots \ldots \ldots \ldots \ldots \ldots \ldots \ldots .1500$ Total cost $\$ 4900$ $£$ s. d.

\begin{tabular}{rrr}
4 & 2 & $21 / 4$ \\
2 & 17 & $61 / 2$ \\
3 & 1 & $73 / 4$ \\
\hline$£ 10$ & 1 & $41 / 2$
\end{tabular}

Average yield 100 bushels; 60 bushels at $\$ 1.75 \ldots \ldots \ldots \ldots \ldots \ldots \ldots \ldots \$ 10500$

40 bushels culls .............. 900

Less the expenditure

$\$ 11400$

Total net profit per acre ... $\overline{\$ 6500}$

\& s. d.

$21 \quad 116$

\begin{tabular}{lll}
1 & 16 & $113 / 4$ \\
\hline
\end{tabular}

£23 86

$\begin{array}{lll}10 & 1 & 41 / 2\end{array}$

$\begin{array}{lll}£ 13 & 7 & 11 / 2\end{array}$

\section{GRAPES.}

Grapes Bring Results.

Ontario's grape output is over 20,000 tons every year, valued at close on $\$ 1,000,000$. Good grape land is plentiful and in the most favored districts may be purchased at $\$ 80$ ( $£ 16$ ) per acre. The fruit begins bearing at four years, and the vines continue to bear for a life time. An Ontario grape grower writes: "We frequently have 5 tons, or 1,500 baskets at $14 \mathrm{c}$. (7d.) or $\$ 210$ ( $£ 43$ 5s.) per acre. Last season grapes on early land averaged 18c. (9d.) per basket."

A grower of grapes near Winona furnishes the following figures, obtained from his results:

Cost of bringing an acre of grapes into

$£$ s. d. full bearing, including support for

vines $\ldots \ldots \ldots \ldots \ldots \ldots \ldots \ldots \ldots \ldots+\$ 7500 \quad 15 \quad 8 \quad 3$ 


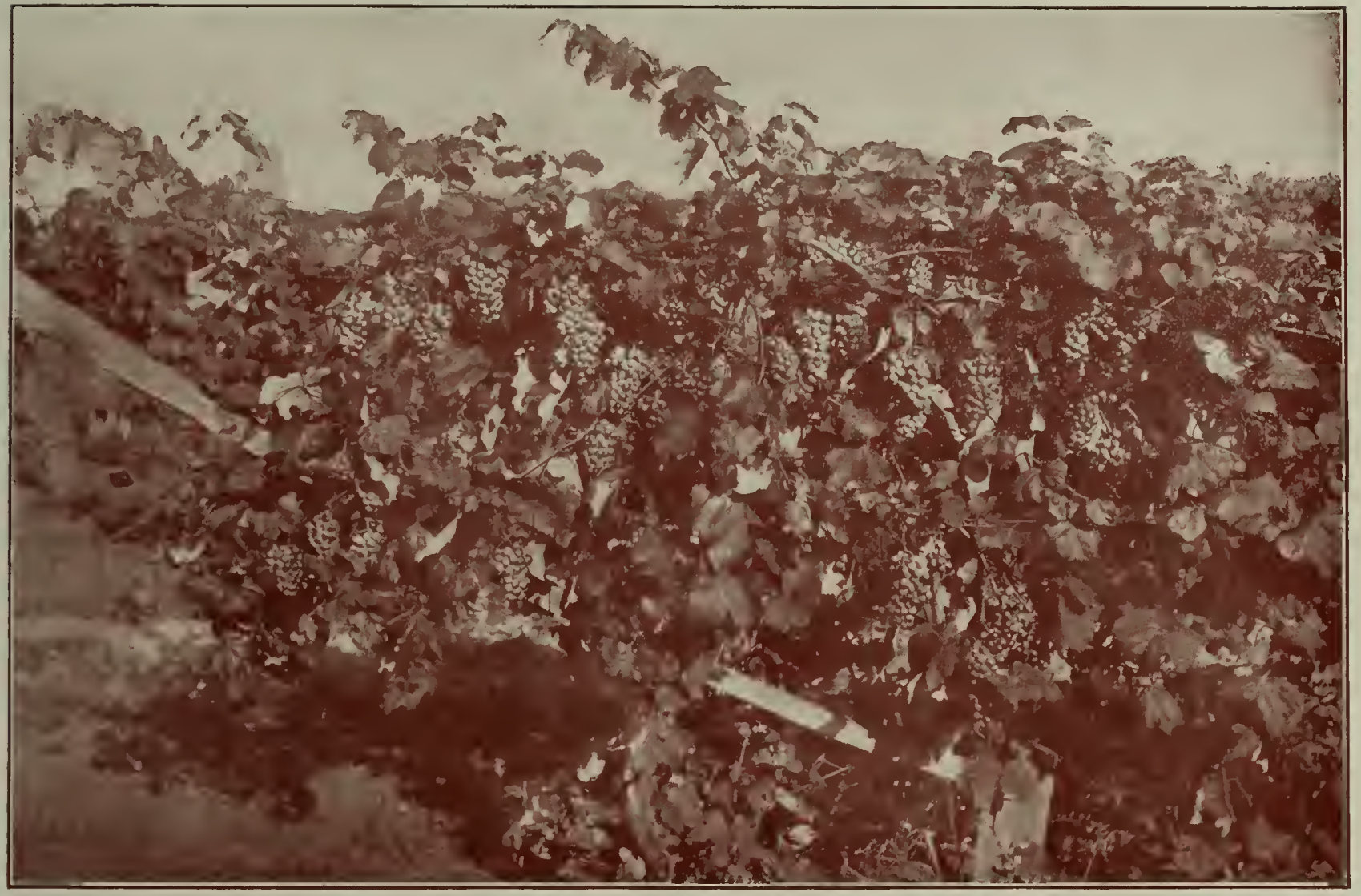


THE COST.

Annual outlay per acre when bearing:

Pruning and tying ............ \$3 00

Cultivation ...................... 750

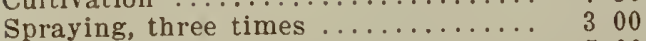

Picking and packages .......... 4500

$$
\overline{\$ 5850}
$$

THE RETURN.

Average yield, 3 tons, or 750 baskets at $15 \mathrm{c}$, average price ......\$112 50

Total net profit per acre ....\$54 00

Another grower, living near St. Catharines, estimates the cost of production as follows:

THE Cost.

Management ................ \$500

Trimming, tying, etc. ............ 750

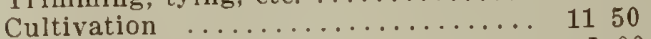

Spraying ................. 500

Fertilizing ................ 1300

Picking, packing and delivering to stations ( 3 tons) ..................... 1500

Baskets, etc. ............. 3200

$\$ 8900$

THE RETURN.

3 tons per acre, or 900 baskets at $14 \mathrm{c} . \$ 12600$ Less expenditure ............ 8900 Total net profit per acre .... \$3700

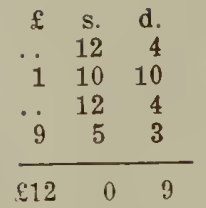

\begin{tabular}{rrr}
$\begin{array}{c}\text { s } \\
23\end{array}$ & 2 & d. \\
\hline 11 & 1 & 7
\end{tabular}

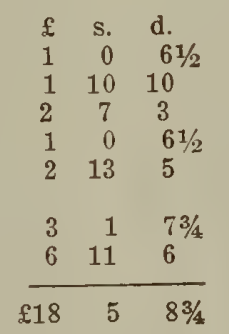

\begin{tabular}{rrr}
$£$ & s. & d. \\
25 & 17 & 9 \\
18 & 5 & 9 \\
\hline$£ 17$ & 12 & 0
\end{tabular}

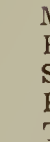

T

\section{STRAWBERRIES.}

\section{Success With Strawberries.}

The strawberry bears the second year from planting, and many growers take the crops from these plantings for two seasons. Others plough the patches up at the end of the first season. The following estimate is furnished by a Beamsrille grower:

First year's outlay per acre:

Manure ................... \$20 00

Plants, 4,840 per m................. 1700

Setting plants .................. 200

Plowing, harrowing and cultivating. . 2400

Two sprayings with bordeaux..... 400
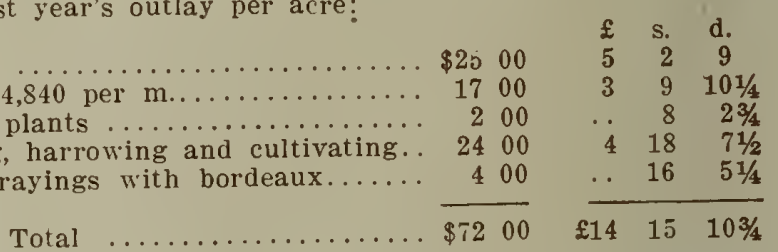

Second year's outlay per acre:

Cultivation and weeding ......... \$32 00

Spraying twice ............. 400

Total

$\$ 3600$

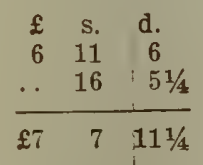

Third year's outlay per acre:

Cultivation and reeding ......... $\$ 800$

Spraying once ............... 200

Total

$\$ 1000$

\& s. d.

$\begin{array}{lll}1 & 12 & 101 / 2\end{array}$

$\because \quad 8 \quad 11 / 4$

£2 $\quad 0 \quad 11 \frac{13}{4}$ 
First year's outlay ............ \$72 00

Second year's outlay

Cost of picking second and third years

crops, 19,200 quarts at 1 c. ....... 19200

Incidental expenses connected with

picking ............................... 960

800 crates at $20 \mathrm{c} \ldots \ldots \ldots \ldots \ldots \ldots \ldots 16000 . \ldots \ldots$

Packing and hauling to station at $5 \mathrm{c}$

per crate .............. 4000

Total cost, three years.....\$606 00

RETURNS.

Second and third year crops, 400 crates

or 9,600 quart boxes, each year.

800 crates, delivered at nearest railway

station at $\$ 1.55$ per crate ...... \$1,240 00

Less total cost ..........606 00

Net return .......... \$63400

Or $\$ 211$ ( $\$ 43$ is.) per annum.

A Burlington grower states: "Placing the arerage crop at, say, 7,500 quarts per acre, and the average price at.6c. at railway station, we get the sum of $\$ 450$ ( $₫ 92.95 .33 / 4$ r.) as the gross receipts per acre. From this deduct the fo!lowing charges:

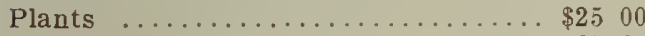

Cultivation ................. 2500

Fertilizers ............... 3500
\&. d.

$\begin{array}{rrr}14 & 15 & 103 / 4\end{array}$

$\begin{array}{lll}39 & 9 & 01 / 2\end{array}$

$\begin{array}{lll}19 & 14 & 61 / 4\end{array}$

$\begin{array}{lll}32 & 17 & 61 / 2\end{array}$

$\frac{8441 / 2}{£ 124 \quad 10 \quad 4^{1 / 4}}$

$$
£ \text { s. d. }
$$

$254 \quad 15 \quad 101 / 2$

$124 \quad 10 \quad 5$

$£ \overline{130 \quad 5 \quad 51 / 2}$

Rent ................. 1j 00

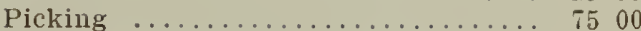

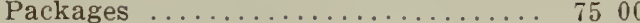

Packing and delivering ......... 2500

Total $\$ 27500$

\begin{tabular}{rcc}
3 & 1 & $73 / 4$ \\
15 & 8 & $23 / 4$ \\
15 & 8 & $23 / 4$ \\
5 & 2 & 9 \\
\hline 556 & 10 & $21 / 4$
\end{tabular}

Leaving a net profit of $\$ 175$ ( $£ 35$ 19s.2d.), a sum which every extensive cultivator may confidently expect to exceed.

\section{CURRANTS.}

\section{Big Figures From Little Currants.}

Sume remarkable results hare been obtained in Ontario from the growing of the smaller fruits. The following actual report on red currants is furnished by a Burlington grower, with 1,200 bushels per acre:

Anneat Cost per Acre.

Cultivation ................ \$8 00

Manure ................... $50 . \ldots$

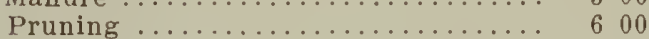

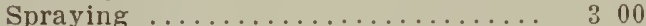

Picking ................... 3000

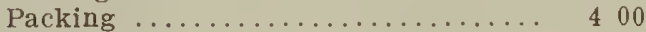

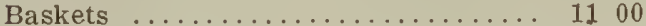

Total ............... \$6700

\begin{tabular}{rrl} 
\pm & $\mathrm{s}$. & $\mathrm{d}$. \\
1 & 12 & $101 / 2$ \\
1 & 0 & $61 / 2$ \\
1 & 4 & 8 \\
$\ldots$ & 12 & 4 \\
6 & 3 & $31 / 3$ \\
$\because$ & 16 & $51 / 4$ \\
2 & 5 & $21 / 2$ \\
\hline 13 & 15 & $41 / 4$
\end{tabular}


ANNUAL RETURN PER ACRE.

Average yield, 2,500 quarts at $5 c . \ldots \$ 12500$ Less outlay ................ 6700

Total net profit per acre ... \$5800

\section{CANNING.}

\section{Canning and Preserving Fruit.}

The rapid development of the canning industry has opened up a new and profitable departinent of farming operations in many sections of the Province. It is one that will yield the grower from 10 to 20 per cent. on the capital invested.

There are 64 such factories scattered pretty well over the Province, but they are most numerous in the Niagara district and in Prince Edward County. In the aggregate they pay the farmers and fruit growers $\$ 800,000$ (£164.600 ) per year for their produce.

The average canning factory prices are as follows:

Vegetables:-

Tomatoes, 25c. per bushel, or $1 \mathrm{~s} .11 / 4 \mathrm{~d}$.

Peas, $\$ 25$ to $\$ 30$ per ton,or $£ 5$ 2s. 9 d. to $£ 63$ s. $31 \frac{1}{2} \mathrm{~d}$.

Corn, $\$ 7$ to $\$ 8$ per ton, or $£ 18$ s. $91 / 4$ d to $\$ 112$ s. $101 / 2 \mathrm{~d}$.

Beans, $\$ 25$ to $\$ 30$ per ton, or $£ 52 \mathrm{~s}$. $9 \mathrm{~d}$. to $£ 63 \mathrm{~s}$. $31 / 2 \mathrm{~d}$.

Pumpkins, $\$ 2.50$ to $\$ 6$ per ton, or 10 s. $31 / 2$ d. to $£ 14 \mathrm{~s}$. $8 \mathrm{~d}$.

Asparagus, $11 \mathrm{c}$. per $1 \mathrm{~b}$., or $51 / 2 \mathrm{~d}$.

Rhubarb, $\$ 8$ per ton, or $£ 112 \mathrm{~s} .10 \% \mathrm{~d}$.
Fruits:-

Apples, 50c. to $60 \mathrm{c}$. per cwt., or $2 \mathrm{~s} .03 / 4 \mathrm{~d}$. to $2 \mathrm{~s}$. $51 / 2 \mathrm{~d}$.

Pears, $11 / 2$ c. to $21 / 2$ c. per lb., or $3 / 4 \mathrm{~d}$. to $11 / 4 \mathrm{~d}$.

Peaches, $31 / 2 \mathrm{c}$. to $51 / 2 \mathrm{c}$. per $1 \mathrm{~b}$., or $13 / 4 \mathrm{~d}$. to $23 / 4 \mathrm{~d}$.

Plums, 30c. to $40 \mathrm{c}$. per basket, or $1 \mathrm{~s} .23 / 4 \mathrm{~d}$. to $1 \mathrm{~s}$. $73 / 4 \mathrm{~d}$.

Gooseberries, $3 c$. to $5 c$. per quart, or $1 \frac{1}{2} \mathrm{~d}$. to $21 / 2 \mathrm{~d}$.

Raspberries, $8 \mathrm{c}$. to $9 \mathrm{c}$. per quart, or $4 \mathrm{~d}$. to $4 \frac{1}{2} \mathrm{~d}$.

Blackberries, $7 \mathrm{c}$. to $12 \mathrm{c}$. per quart, or $31 / 2 \mathrm{~d}$. to $6 \mathrm{~d}$.

Strawberries, $5 \mathrm{c}$. to $8 \mathrm{c}$. per quart, or $2 \frac{1}{2} \mathrm{~d}$. to $4 \mathrm{~d}$.

\section{Location of the Factories.}

The location of the canning factories throughout the Province of Ontario is well scatterch. For convenience in reference their position has heen assigned to four subdivisions of the Province, as follows:

Eastern Onlario, exclusive of Prince Edward county: Brighton (2), Lakeport, Trenton, Port Hope, Belleville, Sapanee, Oshawa.

Prince Edward County: Picton (3), Bloomfield (3), Hillier, Wellington (2), South Bay (2).

Testern Onlario; Strathroy (?), West Lorne, Toronto (2), Meaford, Guelph.

Southern Ontario: Aylmer, Haniliton (5), Waterford, Delhi, Niagara-on-the-Iake, Dunnville ( 2$)$, Grimsby, Kingsville, Sandwich, Chatham, Leamington, St. David's (3), St. Catharines (5), Dresden, Simcoe. Alvinston, Burlington (2), Essex, Welland, St. Thomas, Winona, Beamsville. Tecumseh, Thamesille, Wallacthurg. 


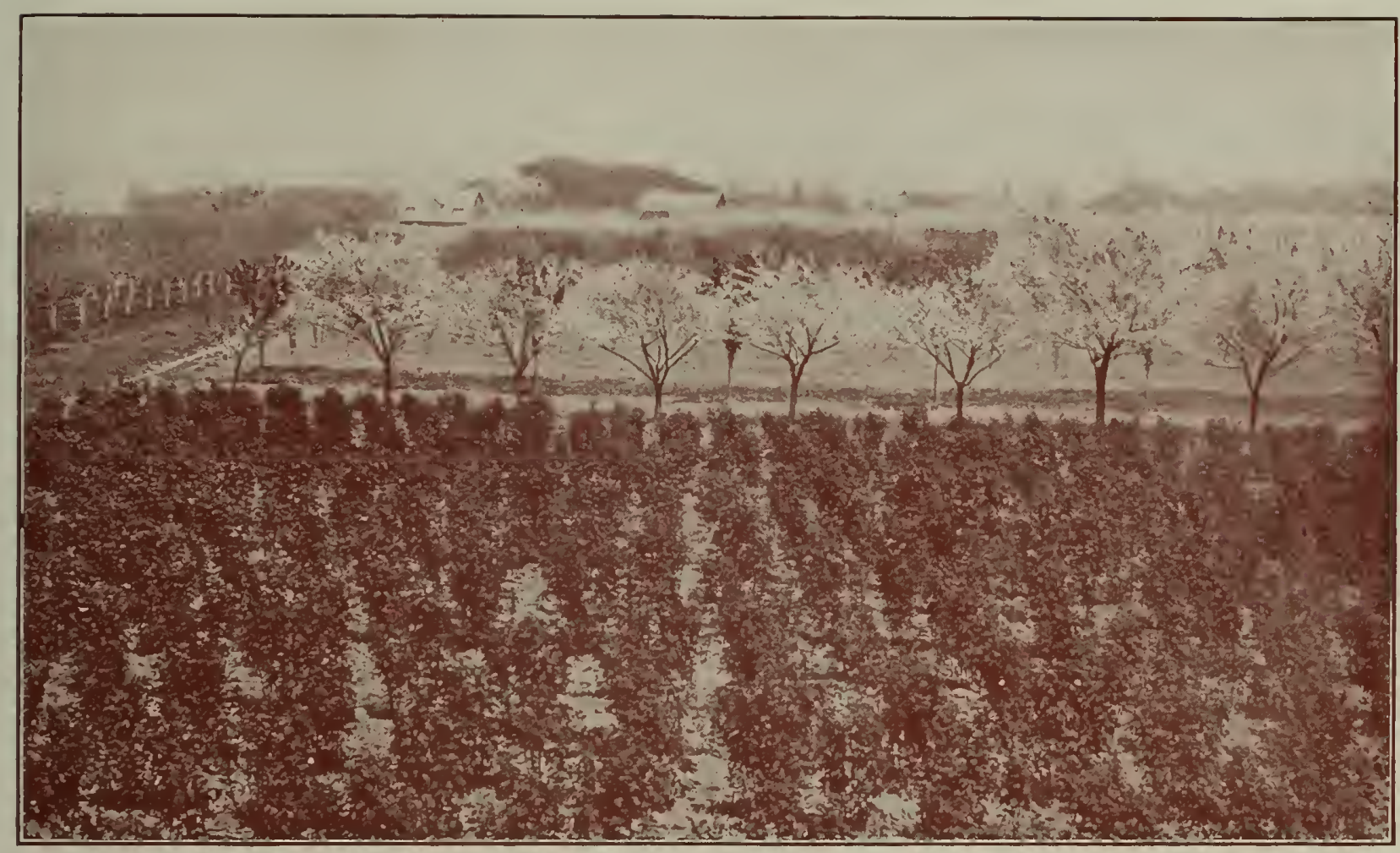

Peaches, Grapes and Raspberries. 


\section{STORY OF TWO FRUIT GROWERS.}

Writing to the Provincial Director of Colonization in Norember 1910, two energetic Englishmen, who have made a success of fruit growing in Ontario, tell their experiences as follows:

\section{From City to Fruit Farm.}

"To have becn born in old London and apparently destined to live one's whole life there, and, in spite of the promise of a financially successful career, to have left all and taken up fruit farming in Ontario, is perhaps a sufficiently interesting fact to be worth recording with some detail. To look back, after a number of years of the new life, and to find that every one of these years has been successful from the monetary point of view, and, what is even more to most people, to find they are ycars of delightful frecdom, robust health and honest comradeship with other fruit growers, is a sequence of facts which will surely be interesting to many who look with longing from within q city on those who gain a livelihood in the open country.

\section{Longed for the Out $=$ of $=$ Doors.}

"In rriting of so drastic a change in life as this, it is almost impossible not to mention ideals, for they play an important part in the appreciation of a new country. We hare felt for a long time that town life was artificial, con- ientional and lacking in the simplicity which is necessary for a healthy, mental and physical cxistence. Te desired the country, but it could only be obtained in the form of an occasional holiday. We wished to simplify our habits, but wcre forced to be conventional in our commercial posiiion. We felt strongly that better than a high salary with the cramping conditions of the city, would be living on our own land, with all our energy given to the cultivation of fruit.

\section{From England to Ontario.}

"We therefore left England and sailed for Untario, arriving in the Niagara fruit district just as the peach orchards were in their gala dress of pink blossom. We had an introduction to people interested in fruit growing, but preferred-and found it better-to go to actual farmers and enquire whether they wanted help.

\section{Making a Good Start.}

"We cxplained our intention of putting in a season of work on a frnit farm with the prospect of making a start for ourselves if it proved satisfactory. Our case was readily understood, and we had no difficulty in getting on just such small fruit farms as we hoped to possess ourselves. The work was hard, for every detail was new to us, but from the first we liked it. in spite of aches and pains from untried muscles. 
The Start of a Fruit Farm.

"In the fall of the same year we purchased ten acres of land, partly planted with fruit, but without buildings on it. We came into possession in November, and immediately started to build house for our accommodation during the coming winter. With the aid of a friendly neighbor, we built a fou "-roomed cottage, which, although it might not have much architectural beauty, was all that was needed for the time, and was arranged on a plan that could be added to as funds allowed and need made necessary.

\section{The Interesting First Year.}

"Early next spring saw us active in carrying out our ideas. We first built a barn with accommodation for two

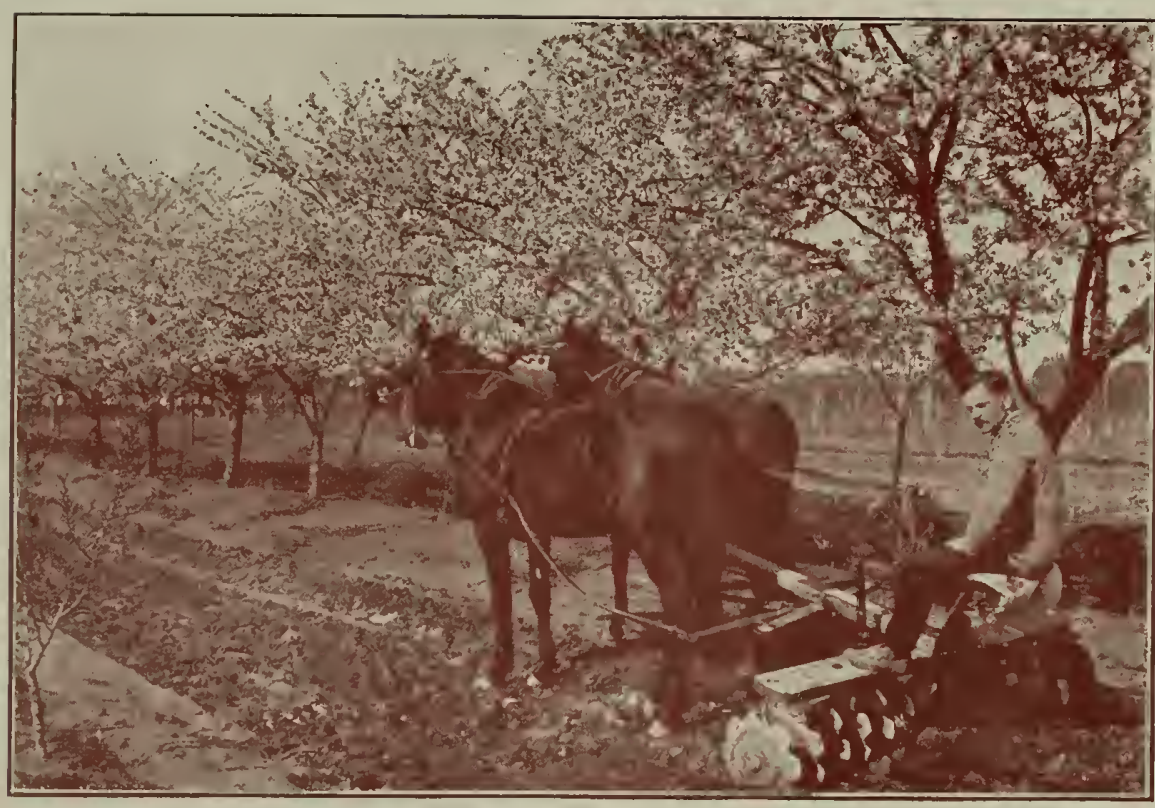

Orchard Cultivation. horses. To start with we purchased only one horse, and only those farm implements which are absolutely necessary. This first year was perhaps the most interesting in our lives, for, like most beginners, we had in mind the idea of making ours an ideal farm, and ample opportunity was

before us to put these ideas into practice. Neighbors were ready enough to give us our first lessons in pruning grape vines and fruit trees. We planted strawberies and raspberries; we sowed a kitchen garden, and even attempted a lawn and flower garden for the house. We cultivated and 


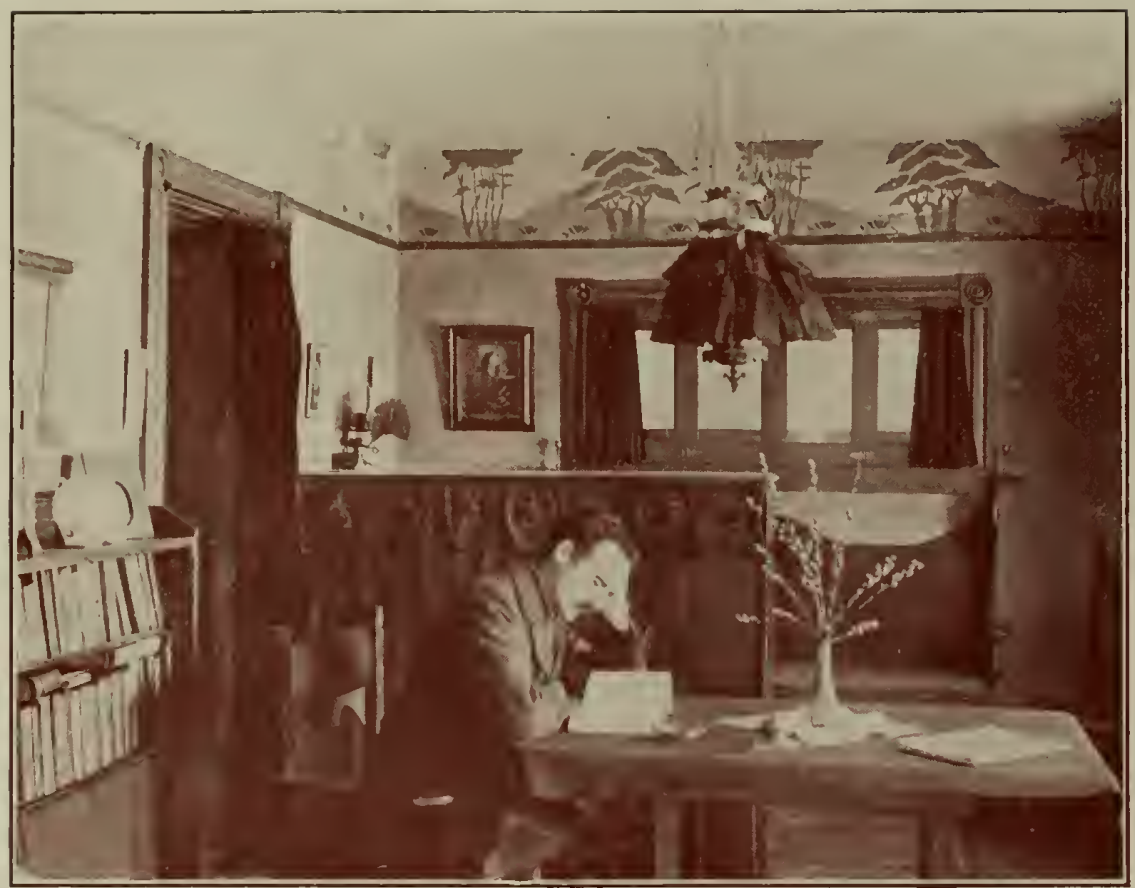

The Writer of this Story at Home.

hoed the warm fertile soil of our farm, and in July had the intense pleasure of harresting our first fruits from our cherry trees.
First Year Brought a Balance.

" Our first season we considered quite a success, for we had good average crops of cherries, plums, peaches, pears and grapes. After all the season's expenses had been paid we liad a balance at the bank, which we intended to devote to further improvements on the farm.

\section{Every Year Better than the First.}

"The succeeding years have all been better than the first, altiough they have naturally differed one from another. We lave improved our house witl the addition of more roms, and lıve it more picturesque, with a porch, shade trees and flowers. We have purchased an adjoining farm, and erected a commodious packing house for our fruit. Old peach trees have been taken out and young ones planted. All of which means much work and careful management, but is irtensely satisfying in every way, for improving conditions by persollal labor is one of the 40 chief jors of fruit farming. 


\section{Reaped Many Advantages.}

"Reviewing our position to-day, we should say that never for one moment have we rcgretted leaving city life for fruit growing. Our work of producing good fruit has a primal simplicity about it that makes for mental ease and true refinement. The out-door labor, the pure air and the proximity of the lake for boating, combine to form a perfect physical culture, and good health is ours. Our house is in the midst of miles of orchard lanes; from our living room windows, beyond the lawn and flowers, beyond vineyard and peach orchards, we see the blue waters of Ontario, and it seems a fitting environment for the healthy, virile art of fruit growing."

The foregoing letter tells its own story of what energy and ambition can accomplish by fruit crowing in Ontario.

\section{OPPORTUNITIES.}

The Opportunities of fered by Ontario.

Ontario has the land-rast quantities of it, most productive in character. Ontasio las the climate-unequaller for frut-growing and farming purposes. Ontario is settled and its peoplc are equipper with all the facilities of modern life. But Ontario is not yet, by any means, developed to its full stature. It nceds more people. It seeks to en- large its happy, contented, successful, home-owning citizenhood. To the new-comer it offers a place among them. 'T'o the man without money it affords the opportunity by thrift and perseverance to rise from the position of farm laborer to that of independent land-owner in a few years. 'I'o the man with small capital it gives the chance of starting at once for himself, and paying for his farm out of his profits from year to year. To the man with money it affords a field of investment which will give sure returns and larger dividends than any other commercial enterprise which he may undertake. Ontario's inducements appeal to every man. Her opportunities are for all alike.

\section{What Ontario Offers to You.}

Are yo?, looking for a Home-a Home of Your Own, a Home of Plenty, a Home of Happiness, a Home of Contented Prosperity? If so this Land of Promise-the Province of Endearor and Achievement-has a Message for You.

\section{You Should Come to Ontario.}

Because it is not a far-off country; it is only seven days from St. Paul's, Iondon.

Because it is the richest, most populous and best developed portion of Britain's new western world.

Because its possibilities are yet unbounded.

Because it offers you the widest possible choice in agricultural achievement. 
Becanse it is the filiul' GR(OWING seetion of Canaclia, prodncing $i$ per cent of all fruits grown in the Dominion; (6) pere (ent. of the plums; 8 per cent. of the apples; 80 pere cent. of the pears and all small fruits, and 99 per cent. of the peaches and grapes.

Because you will be AT HOML. You will be among British people who will be glad to make you welcome.

Because yon will have the best endurational privileges. Ontario's Publie School System leads the way, and Ontario is the centre of IIjgher Edncation in Canada.

Becaure it offers you, free of cost, the assistance of scientific knowlerge in all branelies of Agrieulture, and the adriec of experts at any time for the asking.

Beeause it offers yon more of the soeial comforts and improvements and adrantages of nodern rivilization than any other prospective ficld for emigration.

Because its people aur progressive and prosperous.

Besamse it has room for MILLIONS MORE.

\section{TOBACCO,}

\section{Tobacen Growing in Ontario.}

Tobacen has been successfully grewn to some extent for many rears in South Westeril Ontario, but it was not until about ten rear's ago that it took its place as a staple (rop) in the ('omnties of Fssex and Kent.
As these comntice are at the most southerly extrentity of the whole Inominion of Canada, their mild climate and rich soil seem to insure the finest grarles of tobac(co).

'The firm of IIalker and Sons have located what is believed to be the largest individual tobacen growing farm in the world in Essex county.

Tobacco growing in the Province of Ontario brings large returns from comparatively small investment.

\section{Facts Concerning the Situation.}

The profitable growing of tobacco in Ontario has so far been confined practically to the eounties of Esisex and Kent, but the belief among agriculturalists is that it would prove a profitable crop in any of the Southern sections of the Province.

Many kinds of tobare are grown, such as elewing, smoking and cigar tobaces, but the White Burley, which is a chewing tolaceo, oscupies at the present tine loy far the foremost place.

It is not an uncommon sight to see ficlds ranging from one or two acres to twenty-five or thirty. Messrs. Walker and Sons have the largest individnal tohaeeo field in the world. It covers 260 acres.

South Essex grows abont three-fourtlss of all the tobaeco grown in Ontario, and the growing town of Lenunington is the centre of the tobaceo growing district. 


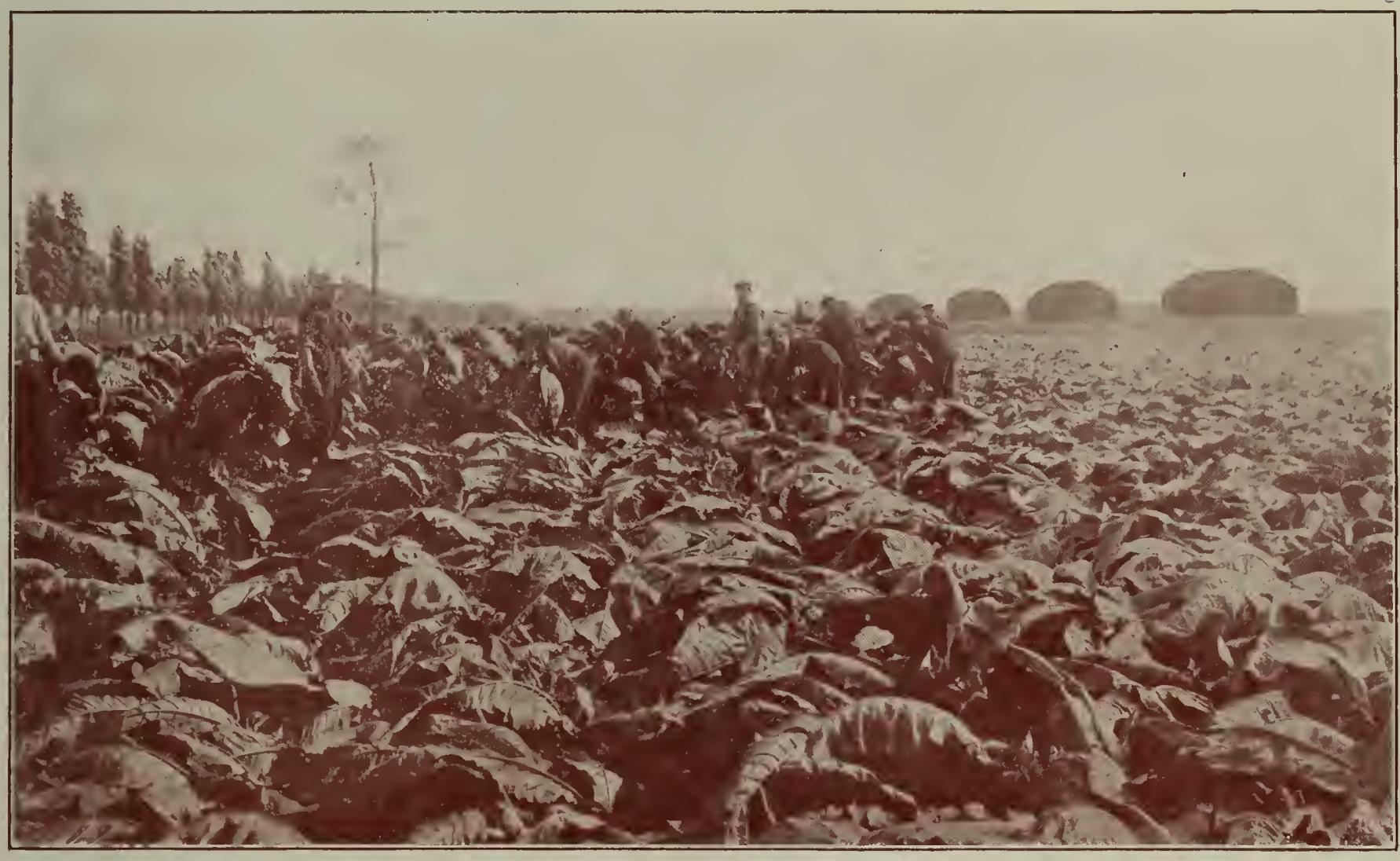

Harvesting Tobaceo. 
Here are located the buyers for the Imperial, Mc $\Delta$ lpine, Dominion, Erie and other Companies, who travel throughout the entire district bidding for the crops.

\section{How Tobacco is Grown in Ontario.}

Tobacco growing in Ontario is one of the most profitable occupations in these southcrn counties.

The plants are raiscd from the seed in beds under cotton or glass till they arc ready to plant in the fierd, which is usually about June 15 th.

If the season is farorable it requires about three months for the tobacco to nlature and ripen before cutting and har vesting.

Most farmers hang the product in barns to dry, while a few dry by heat in barns specially constructed for the purpose.

The majority of the farmers raise their own tobacco plants, but some prefer to buy from their neighbors.

\section{A Word on What has Been Done.}

The actual cxpense of growing an acre of tohacco in Ontario, outside of supplying the plants which any farmer can raise for himself, is figured to be $\$ 50(£ 10)$.

The crop yields from $1,000 \mathrm{lbs}$. to $2,000 \mathrm{lbs}$, but an average crop would be $1,250 \mathrm{lbs}$. to the acre.
The pricc varies from year to year, being 15 cents $(\boldsymbol{F} \mathrm{I} / 2 \mathrm{~d}$.) per $1 \mathrm{~b}$. in 1909 , while the average price in 1910 was 17 cents $(81 / 2$ d.).

\section{Actual Results in 1910.}

The actual figures for 1910 are as follows: ESSEX COUN'TY-4,100 acreage; 1,250 lbs. per acre; 17 cents $(81 / 2 \mathrm{~d}$.) price per lb.; $\$ 212.50$ ( $\$ 43)$ amount per acre; or a total of $\$ 871,250(£ 174,250)$. KENT COUNTY1,400 acreage; 1,250 lbs. per acre; 17 cents $(81 / 2 \mathrm{~d}$.) price per lb.; $\$ 212.50(£ 43)$ amount per acre; or a total of $\$ 297,500(£ 59,500)$.

It will thus he seen that an acre produced this year (1910) $\$ 212.50(£ 13)$, the total cost being $\$ 50$ ( $£ 10)$, leaving the grower a profit of $\$ 162.50$ ( $£ 33$ ) per acre.

In all 6,875,000 lbs. were grown in Essex and Kent in 1910, and four times the amount can easily be produced in these counties by increased acreage.

\section{What Growers Have Done in Ontario.}

Numbers of instances were reported in 1910 where farmers rcalized over $\$ 200(£+0)$ per acre on their tobacco crop. 


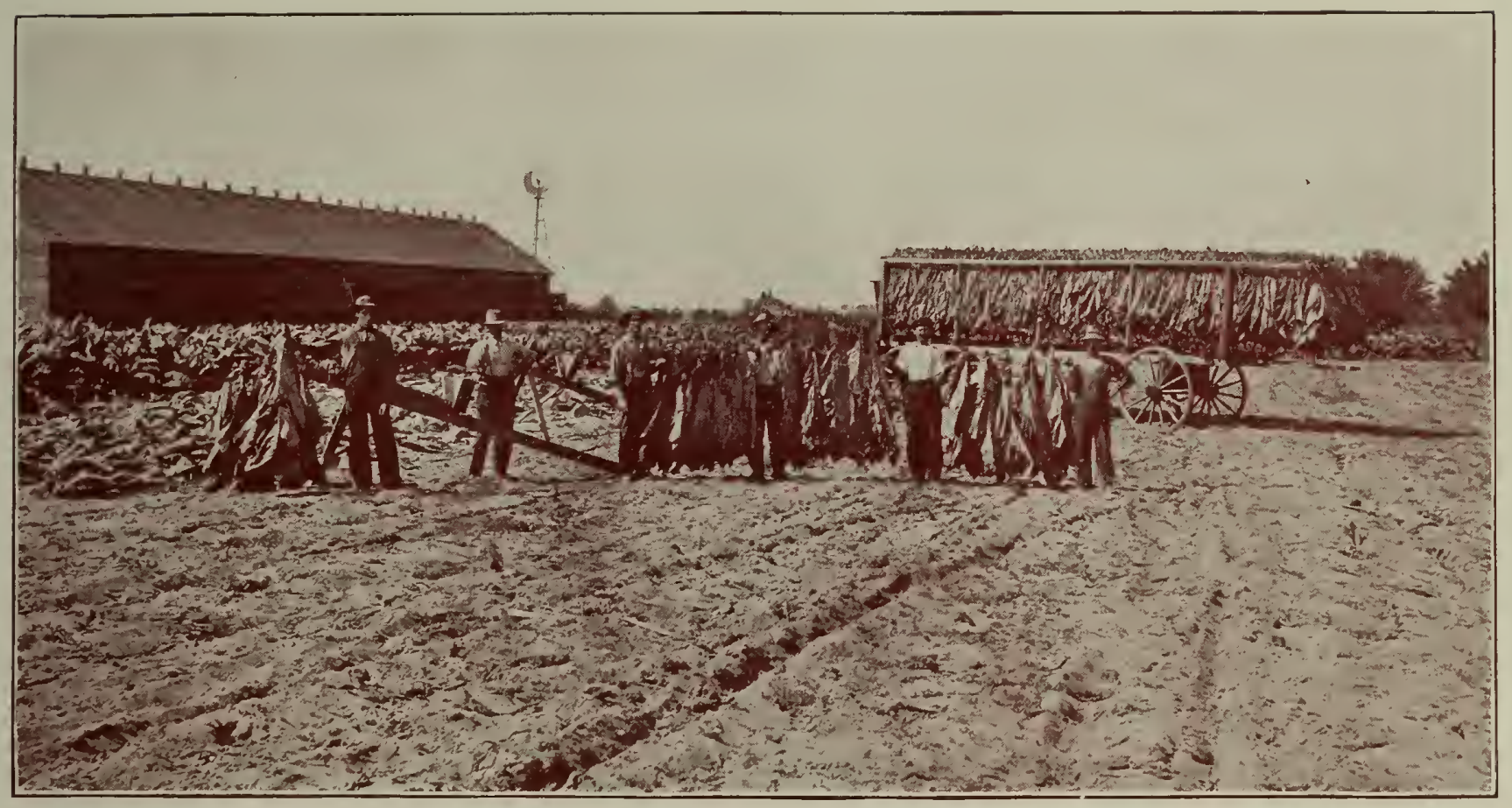

Hauling Tobacco to the Curing Barns. 
'The following are the estimates given by a few farmers for 1910 , with prices:

Richard l'rosser, I,eamington John Moore Lemuel Sloan

Everett Dresser Burns Wilkinson

J. J. Wilkinson

Robert Grant

culbert White

Fred Wigle

George Evans

Sphraim Stockwell

James Howie,

Harrow

Walter McCormick

Albert Klie

Henry Klie

R. Martin

D. Brown

IV. R. McGregor, Ridgetown

fewell \& Snow

J. II. Stevens

N. Ml. Campbell

Leonard Malott,

"
"
"
"
"
"
Harrow
".
"
"
Ridgetown
".
".
Leamington

"The following list of prices paid to various wellknown Kent farmers", said Mr. (iregory in his published statement, "will give some indication of the profits of tobaceo growing this year:

"II. IV. Arnold, Louisville, nine acres, received $\$ 2,400$ (£480) for lis crop.

"George Blackhurn, Louisville, nine acres, received $\$ 2,300$ ( $£+60)$ for his crop.

"IV. Pickering, Chatham Thwnship, seren acres, received $\$ 1,680$ ( $\$ 336$ ) for his cropl.

"George Stephens, Harwich, ten acres, receired from $\$ 1, \$ 00$ to $\$ 2,000$ ( $\$ 360$ to $\mathfrak{E} 400$ ) for his crop.

"William Snow, Blenheim district, 28 acres, received $\$ 6,500(£ 1,300)$ for his crop.

"IT. R. MI Gregor, 22 acres, received $\$ 5,500 \quad(£ 1,100)$ for his crop.

"Teil Camphet!, 12 acres, received $\$ 3,200$ ( his crop."

\section{A HOME.}

\section{Are You Looking for a Good Home?}

The Province of Ontario offers every inducement to of the Imperial Tolaces Company, of Montreal, published in the Chatham Planet, in the autumn of 1910, that gen. tleman saic his ('ompany had purehased $\$ 1,000,000$ $(£ 200,000)$ wortl of tobaceo in the counties of Esséx and Kent, and were still looking for more. the Home-Seeker. Its splenilid resources, rieh soil and ideal climate make sucess for the industrious sottler assured. 


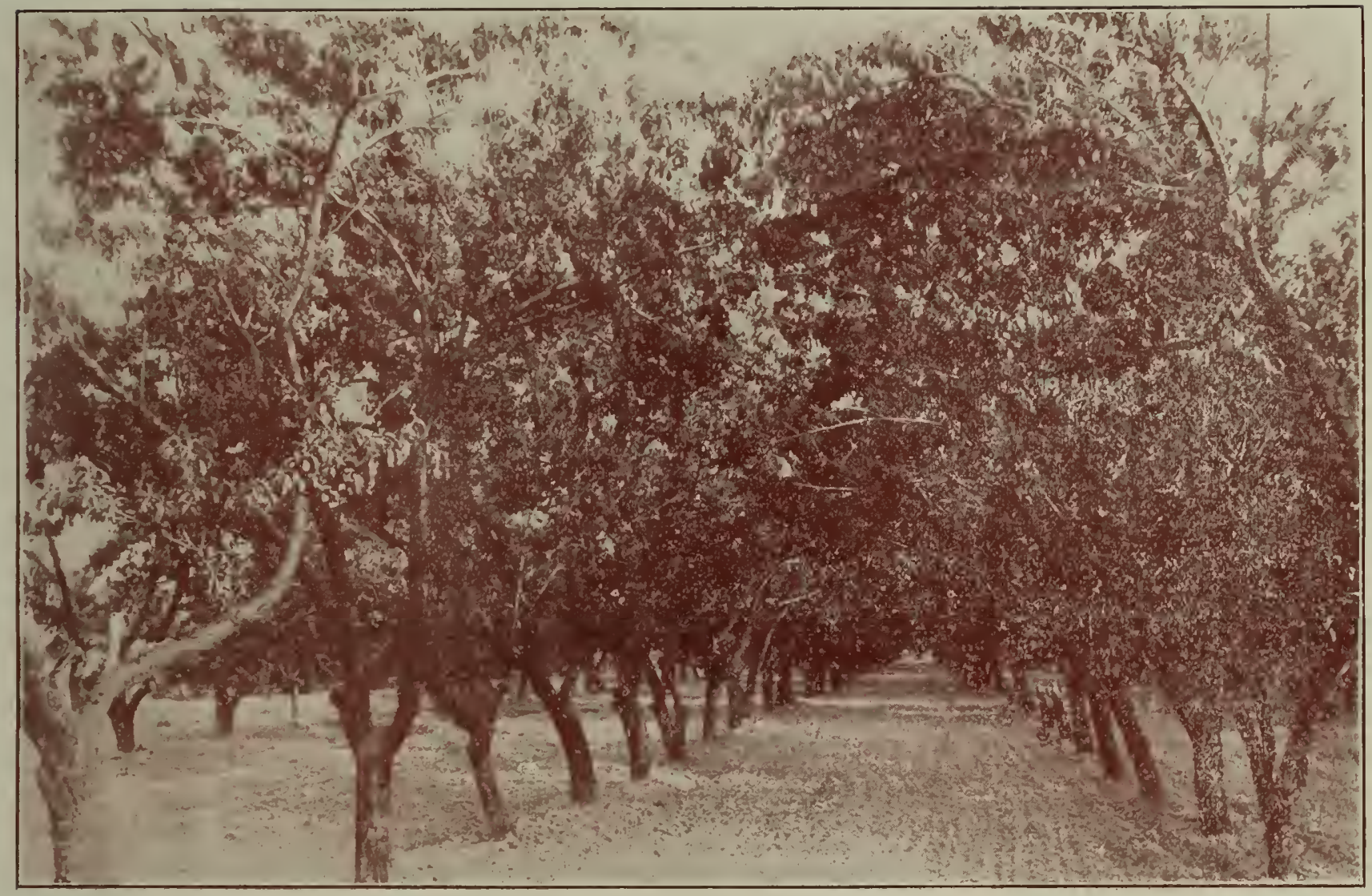

Old Peach Orchard. 
Ontirio possesses all the advantages. The pioneer work is done. The country is opened up. All portions are now served with chmrches, schools, railways, telegraph, telephone, laily newspaper, and all other advantages of modern rivilization.

For further particulars write to

DONALD SUTHERLAND,

Director of Colonization,

Parliament Buildings,

Toronto, Ontario, Canada,
Ontario needs population -inereased population. The Province will extend a welcome and give an unequalled opportunity to those who would establish a good home of their own in an ideal British country.

Orỹ to

N. B. COLCOCK,

Ontario Government Agent, 163 Strand,

London, W.C., England.

Printed by WILLIAM BRIGGS,

29-37 Richmond St. W., Toronto. 

$\begin{array}{lllll}\text { SPCL } & \text { SB } & 354.6 \quad C 2 & 058\end{array}$

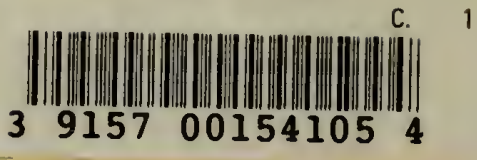

Spel

$S B$

354 BROCK UNIVERSITY

ST. CATHARINES, ONTARIO

C2058

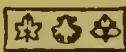

敞经任

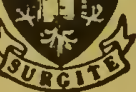

LIBRARY 


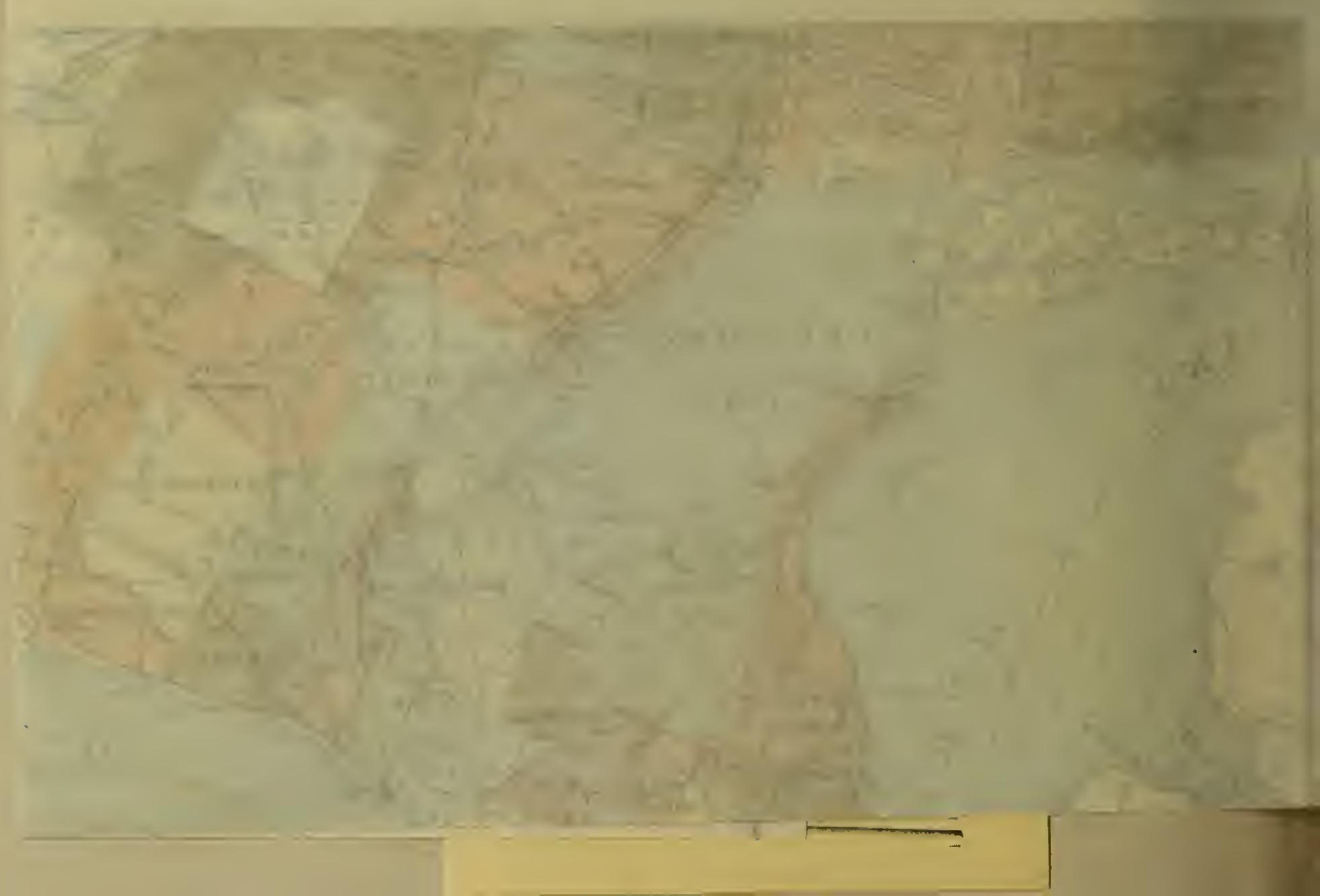




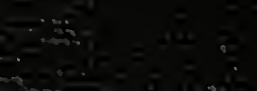

